\title{
Responsible Production for Sustainability: Concept Analysis and Bibliometric Review
}

\author{
Fuzhen Liu ${ }^{1}\left(\mathbb{D}\right.$, Kee-hung Lai ${ }^{1, *(\mathbb{D})}$ and Wei Cai ${ }^{1,2}$ \\ 1 Faculty of Business, The Hong Kong Polytechnic University, Hong Kong 999077, China; \\ fuzhen.liu@connect.polyu.hk \\ 2 College of Engineering and Technology, Southwest University, Chongqing 400715, China; weicai@swu.edu.cn \\ * Correspondence: mike.lai@polyu.edu.hk
}

check for updates

Citation: Liu, F.; Lai, K.-h.; Cai, W. Responsible Production for Sustainability: Concept Analysis and Bibliometric Review. Sustainability 2021, 13, 1275. https://doi.org/ $10.3390 /$ su13031275

Received: 6 January 2021

Accepted: 22 January 2021

Published: 26 January 2021

Publisher's Note: MDPI stays neutral with regard to jurisdictional claims in published maps and institutional affiliations.

Copyright: (c) 2021 by the authors. Licensee MDPI, Basel, Switzerland. This article is an open access article distributed under the terms and conditions of the Creative Commons Attribution (CC BY) license (https:/ / creativecommons.org/licenses/by/ $4.0 /)$.

\begin{abstract}
Responsible production is receiving growing attention in manufacturing operations, but systematic analysis of its concept is scanty. This paper aims to advance the knowledge by examining the research evolution of responsible production for sustainability. Using the concept analysis approach, we first summarize four underlying attributes, including the change to sustainability, preventive initiatives, process management, and company-specific context. Next, we identify that contextual factors and firm characteristics are antecedents of responsible production, which consequently affects customer attitude, employee behavior, and firm performance. Through a bibliometric review of 518 most relevant articles, we observe that responsible production for sustainability has seen a research boom in developing countries and that China is one of the most conspicuous countries in this regard. We also recognize that the link of responsible production and financial performance receives particular interest, but it needs a more synthesized assessment framework. To promote research development of responsible production for sustainability, research collaboration, either at the author or country level, is highly desirable for knowledge creation and transfer. In view of the growing interest on its performance value, we propose a research framework with guideposts for studying responsible production and financial performance. This review provides managerial and policy implications for responsible production with insights to advance knowledge in this emerging research field.
\end{abstract}

Keywords: responsible production; sustainability; concept analysis; bibliometric review

\section{Introduction}

The past decades have seen growing importance for firms to implement responsible production in achieving sustainability goals [1]. The neglect for responsible production can lead to serious problems including environmental degradation, resource shortage, and human health risks [2]. Policymakers have made progress on responsible production to address these issues. Extended producer responsibility (EPR) laws obligate producers to address the externalities caused by end-of-life products at the post-consumption phase [3]. Original equipment manufacturers (OEMs) are mandated to collect and recover wastes arising from their products, which are no longer handled by municipal authorities [4]. Producers are expected to manage their upstream and downstream activities for lesser resources consumption and pollution caused to human health and environmental sustainability [5]. Moreover, the United Nations has emphasized responsible consumption and production (Sustainability Development Goal (SDG) 12) as one of the seventeen sustainability goals, advocating a sustainable/green way to consume resources and produce goods [6].

Despite the importance of responsible production, there is no consensus on its definition. As a manifestation of corporate social responsibility (CSR), responsible production has appeared in the literature, but it lacks widespread recognition. Zhao et al. argued that responsible production can prevent hazard accidents and benefit the environment 
because process safety management requires stakeholder engagement for reducing risks [7]. Skouloudis et al. mentioned that responsible business behavior should be attached greater importance, especially in product/service responsibility and responsible marketing, indicating that responsible production is one of the top CSR priorities [8]. A previous literature review has investigated the concept of sustainable production and consumption (SPaC) for characterizing the business focus, stressing the coexistence of production and consumption [9]. Yet, it gives no clue on how to conceptualize responsible production, which is one of $\mathrm{SPaC}$ implementation mechanisms, with a standalone focus. Responsible production is a risk-reduction and value-creation approach integrating CSR, process management, and emergency preparedness [7]. The scant literature gives a clear definition of responsible production, although it is distinguished from CSR because responsible production emphasizes product/production-oriented responsibility [8]. This research gap motivates us to examine the concept of responsible production.

Numerous studies have linked responsible production practices to the achievement of SDGs; less attention is paid to mapping the research status and development of responsible production for sustainability [10,11]. Integrating responsible production practices into the SDGs will enable enterprises to gain multiple benefits in the long run. For example, responsible production can reduce operational costs by resources saving and improving product quality due to the legitimacy to meet public expectations [12]. A previous literature review has summarized that the development of sustainable production methods in machining is to reduce pollution and improve efficiency [11]. However, it focuses on production methods and confines its perspective to the ecological sustainability. Geng et al. adopted a bibliometric analysis of 447 articles and outlined the research of sustainable design for users [10]. Yet, it concentrates on product design and involves no specific understanding of the relationship between responsible practices and SDGs. Responsible production encourages the responsibility of supervising and managing product life cycle, covering a broader process. Zimon et al. recognized that the integration of responsible practices with sustainability is highly challenging and requires an adequate understanding of their relationship [13]. Thus, it is worthwhile to capture responsible production for sustainability in the literature and conduct a comprehensive review of existing research.

This study provides a systematic concept analysis on responsible production and a bibliometric review of its link to sustainability. It addresses a research gap by defining the concept of responsible production and reviewing its literature development with a focus on sustainability [9]. This work provides a comprehensive overview of responsible production studies with a research agenda for future directions to extend this line of research.

\section{Concept Analysis of Responsible Production}

Concept analysis is a qualitative research method to identify a clear definition and description of a concept [14]. Numerous studies have adopted concept analysis to define a concept, laying a theoretical foundation for related literature $[15,16]$. This method is often applied to define concepts in non-business field such as nursing [14] and recently in production and operations management [17]. The application of concept analysis comprises two steps [14]. It begins with a general search for clarifying the definitions and usages of a concept through an exploratory and broad search on the Internet. A literature search is the next step by inputting search terms in scientific databases for capturing the defining attributes, antecedents, and consequences of a concept and then developing cases and empirical referents that illustrate the concept.

\subsection{General and Literature Search}

For concept analysis of "responsible production", the search term "responsible production" is executed in databases of Google, Wikipedia, corporate websites, and online dictionaries. To identify its attributes, antecedents, and consequences, our literature search focuses on empirical studies. As the term "responsible production" is emerging in the literature, we refer to $[7,18]$ for the search rule of this concept as comprising two parts: 
"responsible" (producer-focused responsibility) and "production" (production-oriented practices). Two scholars in green manufacturing and sustainability were consulted to refine this search rule. The dimension of "responsible" includes environmental responsibility, social responsibility, corporate responsibility, and producer responsibility [19]. Following the extant literature [18], the keywords for "production" (i.e., production, manufacturing, product management, and operation/operations) are used to search the "title, abstract, keywords". The time span was set as "all year" to ensure that the searched articles cover as many time periods as possible. As a large abstract and citation database, Scopus was employed to complete the search for the literature review because it contains a large volume of journals published by Elsevier, Springer, Informs, Emerald, and MDPI [20]. Furthermore, Scopus is wider in scope to capture a more comprehensive range of research fields than that of Web of Science [21]. This study used the Scopus database, and all the search was completed in January 2021. After eliminating duplicates and reviewing articles' relevance, 317 empirical studies remained for further analyses.

\subsection{Definitions and Use of the Concept}

The components of responsible production are found in various dictionaries. For example, the Oxford English Dictionary defines "responsible" as "of a practice or activity: carried out in a morally principled or ethical way". In addition, "production" is defined as "the action or process of making goods from components of raw materials and the manufacture of goods for sale and consumption". Moreover, according to corporate announcement, a technological center (Azti-Tecnalia) values responsible production for preventing irreparable damage to the environment by introducing structural changes to the production model. It highlights corporate responsibility at different stages of the product life cycle with commitment to finding new solutions of sustainable production mode to avoid resource wastage and generate more efficient production processes [22].

Responsible production, extracted from responsible consumption and production (SDG 12), underpins that we progressively change our production pattern toward a more sustainable future. The purpose of responsible production is to "do more and better with less" [6]. It highlights the essence of "decoupling economic growth from environmental degradation, increasing resource efficiency, and promoting sustainable lifestyles". The definition provides a clear statement regarding the purpose of responsible production, yet it is too generic compared with similar concepts such as sustainable production. In addition, scant literature has explicitly defined "responsible production" with detailed and distinct features.

There are concepts similar to responsible production in the literature, as summarized in Table 1. For instance, lean production emphasizes resources efficiency [23], green production values environmental protection [24], and sustainable production highlights the importance of sustainable development toward triple bottom line (TBL) [25]. In addition, cleaner production is defined as "a preventive, company-specific environmental protection initiative for minimizing waste and emissions and maximizing product output" [26]. Notably, previous literature has indicated that responsible production follows the principle of sustainable production, highlighting "the production of products, services, and resources in a manner which is environmentally benign, economically viable, and socially beneficial" [9]. Keskin et al. argued that the purpose of sustainable production for enterprises is to make products and production processes cleaner and more efficient [27]. Furthermore, socially responsible production means that products are produced in a socially responsible way [28]. Environmentally responsible production emphasizes low emission rates, such as zero-emission, in the operations process [29]. In sum, responsible production is highly desirable for firms to achieve sustainability and prevent risks in production and operations management [30]. 
Table 1. Some concepts similar to responsible production.

\begin{tabular}{|c|c|c|}
\hline Concepts & Definitions & Sources \\
\hline $\begin{array}{l}\text { Environmentally conscious } \\
\text { manufacturing }\end{array}$ & $\begin{array}{c}\text { It involves the planning, development, and } \\
\text { implementation of manufacturing processes to reduce } \\
\text { hazardous waste, design recyclable products, and } \\
\text { guarantee safer operations. }\end{array}$ & {$[31]$} \\
\hline Lean production & $\begin{array}{c}\text { It uses a reduced level of input resources for a given } \\
\text { level of output. }\end{array}$ & [23] \\
\hline Green production & $\begin{array}{l}\text { This practice aims at achieving greenness and } \\
\text { sustainability at the stage of manufacturing. }\end{array}$ & {$[24]$} \\
\hline Sustainable manufacturing & $\begin{array}{l}\text { It is defined as producing products in a way that } \\
\text { minimizes environmental impacts and takes social } \\
\text { responsibility for employees, the community, and } \\
\text { consumers throughout a product's life cycle while } \\
\text { achieving economic benefits. }\end{array}$ & {$[32]$} \\
\hline Sustainable production & $\begin{array}{l}\text { The creation of discrete manufactured products is to } \\
\text { fulfill their functionality over their entire life cycle, cause } \\
\text { a manageable number of impacts on the environment } \\
\text { (nature and society) while delivering economic and } \\
\text { societal value }\end{array}$ & [25] \\
\hline
\end{tabular}

\subsection{Attributes}

Responsible production has four defining attributes. The first one is the change to sustainability because the purpose of responsible production is to achieve sustainable development of TBL [6]. Notably, 265 out of 317 empirical studies have examined the effects of responsible production practices on sustainable performance, including financial [33,34], operational [35], social [36], and environmental aspects [37]. The majority of articles concern financial assessment on responsible production practices [38]. The second is that the initiatives are preventive in nature for reducing risks. Previous literature has demonstrated that responsible production is a risk-reduction instrument, as it helps firms prevent risks [39], such as financial risk [40], market risk [41], and operational risk [42]. The third is that responsible production relies on process management implemented by enterprises. Responsible production emphasizes corporate sustainability management in business operations [43]. It covers the whole production process and product life cycle from product development, manufacturing, and customer use to waste disposal [44]. The last attribute is a company-specific context. Although SDG 12 requires that consumers and producers are responsible for consumption and production, responsible production underlines corporate responsibility toward achieving a more sustainable economy that works for both people and the planet. Numerous studies highlight enterprises' sustainable practices, especially for manufacturing firms [45] and heavily polluting companies [46].

\subsection{Cases}

Following [14], we develop four cases to illustrate how the defining attributes manifest in actual practices. Table 2 presents two model cases of responsible production and two contrary cases about irresponsible production. We also explain why these cases are model/contrary according to the existence/absence of the defining attributes of responsible production. 
Table 2. Model and contrary cases of responsible production in enterprises.

Types

Model case 1

Model case 2

Contrary case 1

Contrary case 2

\section{Cases}

Teck provides durable and naturally recyclable commodities required for sustainable products and infrastructure. Teck is working to reduce waste and pollution, keep products in use, and help to improve the natural environment [47].

This case demonstrates responsible production. This firm has a commitment to create a sustainable environment to eliminate wastes and emissions by offering durable and recyclable ingredients in product design.

Huawei has managed to reduce the power consumption per $5 \mathrm{G}$ site by using innovative technologies and used about 932 million kWh of electricity from clean energy sources to reduce emissions [48].

This case supports a good example of responsible production. This firm seeks a more energy-efficient solution to build a low-carbon economy using innovative technologies. It illustrates the change to sustainability and resource saving by adopting preventive initiatives in resources input.

Untreated toxic wastewaters from textiles factories are dumped directly into the rivers when garments are produced [49].

This case demonstrates a lack of responsible production, because these factories ignore environmental sustainability. Their actions have threated people's health and brought a negative environmental effect.

Corporations involved in the palm industry employed child labor and cut tropical forests for palm oil plantations by destructing the peatlands, releasing up $\mathrm{CO}_{2}$ into the atmosphere [50].

This case illustrates irresponsible production because the firms have caused a negative environmental damage and disrupted social rules. They lack the responsibility to achieve sustainable development.

\subsection{Antecedents}

Walker and Avant argued that antecedents are events or conditions that take precedence over a concept occurring [14]. Regarding the antecedents of responsible production, extensive studies have suggested that contextual factors drive firms to implement responsible production practices. Environmental regulatory pressure [51], customer pressure [52], and stakeholder pressure [53] are the pushing forces, while information and technology [54], expected benefits (e.g., efficiency and competitive advantage) [44], and globalization [55] are the pulling forces. Top management leadership [56], organizational culture [57], and corporate responsibility orientation [44] are three critical factors related to firm characteristics, promoting responsible production practices adoption.

\subsection{Consequences}

Consequences are the outcomes of a concept occurring [14]. Responsible production can lead to sustainable development based on TBL. Specifically, responsible production is associated with (a) firm-level performance, (b) customer-level attitude, (c) employeelevel behavior, and (d) others. In terms of firm-level performance, it can be divided into financial and non-financial performance. The former mainly contains accounting-based return on assets (ROA), market-based (Tobin's Q), and perception-based financial performance $[33,34]$. The latter involves tangible performance, such as operational efficiency [46], labor productivity [58], quality performance [59], environmental sustainability [60], social welfare [61], and intangible performance covering trade credit [62], image, brand, reputation [63], and trust [64]. Moreover, responsible production practices trigger a series of consumer responses, such as consumers' loyalty [65], customer satisfaction [66], customer perceptions and purchase intentions [67]. Employees' behavior [57], employee commitment [68], employee task performance [69], employee citizenship behavior [70], job satisfaction [71], and employee productivity [72] are the consequences of responsible production. Moreover, responsible production can lead to supplier collaboration [68] and stakeholder satisfaction [73]. 


\subsection{Empirical Referents}

Regarding the antecedents and consequences of a concept, empirical referents can illustrate a concept with the defining attributes [14]. For example, scholars summarized four antecedents of eco-design initiatives, including regulations, customer pressure, social responsibility, and expected business benefits [74]. Eco-design initiatives positively influence the environmental, economic, and intangible outcomes [74], which are closely related to sustainability. Environmental regulatory pressure, customer pressure, environmental uncertainty, expected business benefits, and social responsibility are identified as driving forces, urging enterprises to implement waste, energy, and resource management practices in business operations, promoting sustainable performance [51]. Meanwhile, evidence has shown that corporate social irresponsibility brings financial risk and credit risk [40]. Nonetheless, corporate environmental performance can reduce firm risk in the manufacturing sector by implementing responsible production practices [39]. Figure 1 presents the antecedents, attributes, and consequences of responsible production. The next section analyzes what has been done in the literature concerning responsible production with a focus on sustainability based on a bibliometric review.

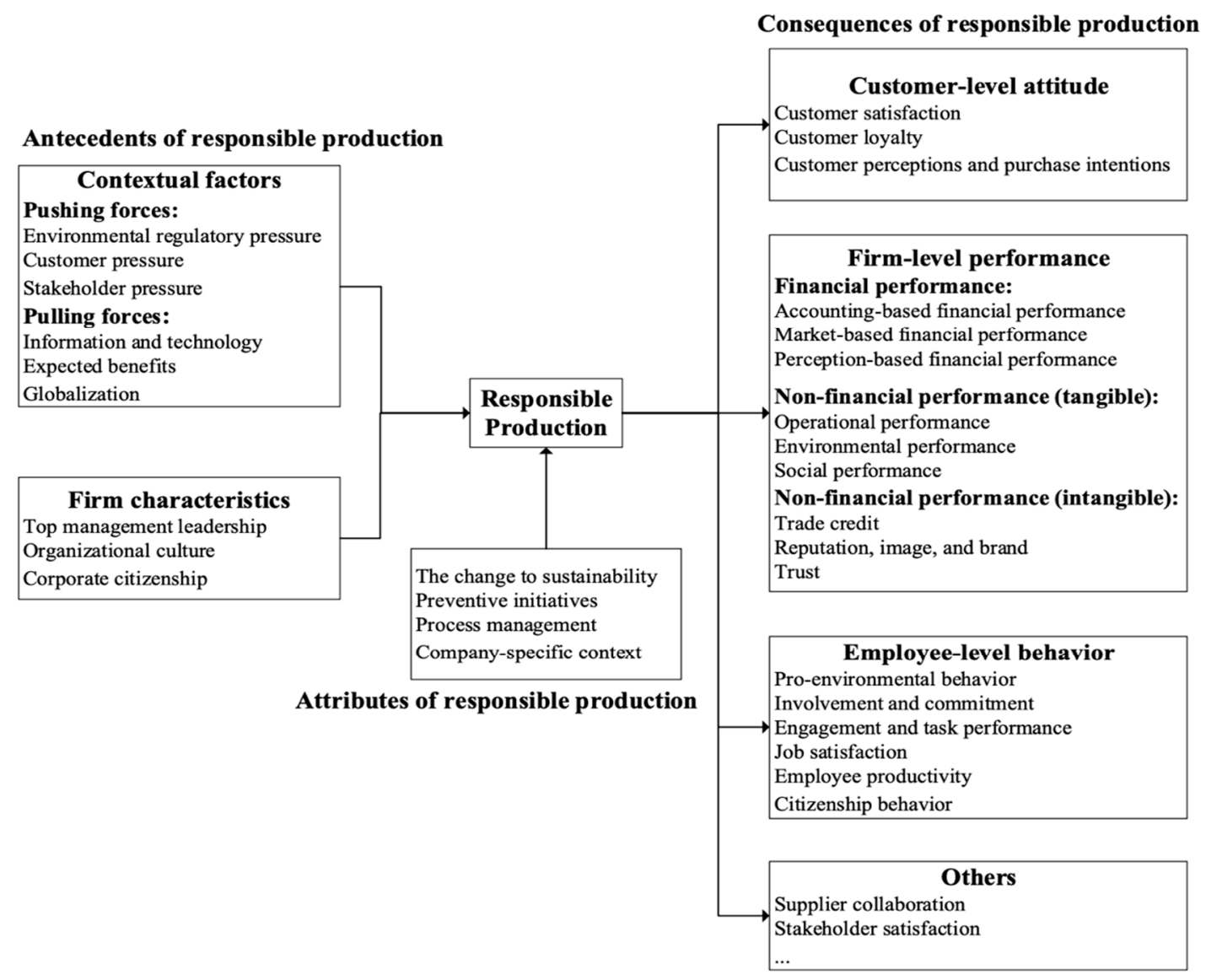

Figure 1. Antecedents, attributes, and consequences of responsible production.

\section{Bibliometric Review on Responsible Production for Sustainability}

A systematic literature review (SLR) depicts an objective summary of what has been done previously on a particular research topic [75] and summarizes what is unknown about a specific practice-related question [76]. It often follows five well-structured steps [77]. First, the main research question is clarified. Second, databases and search terms are determined, and articles are selected according to the inclusion/exclusion criterion. Third, we conduct a thematic analysis for the selected articles. The fourth step is to figure out significant patterns and research gaps. Finally, the results are presented. 
Bibliometric analysis, as a kind of research methods for SLR, has an advantage in depicting the overall development trend of a specific research field that covers numerous related articles [78]. Further to concept analysis, we adopt a bibliometric method to review previous literature from a holistic perspective. First, compared with qualitative analysis on SLR, bibliometric analysis can objectively process a large number of articles and outline a comprehensive picture of a particular research topic. Second, such a method can visualize research content and map research trends using Citespace, Vosviewer, and other visualization tools. It helps readers quickly capture useful information and understand the overall research directions in a specific field. Third, considering keywords and citations are two key elements constituting an article, bibliometric analysis can figure out their inner relationship among articles through keywords co-occurrence and co-citation analysis.

In this study, we divide our bibliometric review into two parts. First, we adopt VOSviewer, which is a scientific knowledge mapping software proposed by van Eck and Waltman, to perform several visual analyses [79]. These analyses are, respectively, keywords co-occurrence, reference co-citation, country co-authorship, and term co-occurrence. Second, Citespace, a java-based application for mapping research trends in the scientific literature, is employed to depict the dynamic evolution of themes over time [80].

\subsection{Literature Position}

Achieving TBL involves three dimensions of economic, social, and environmental development [81], depicting the goals of economic prosperity, environmental protection, and social equity. Rockström argued that sustainability is an integrated concept, identifying planetary boundaries and preventing human activities from causing irreparable environmental damage [82]. Researchers have emphasized the importance of integrating sustainability into operations and strategic management, as sustainable practices can lead to operational efficiency and cost reduction [12]. Numerous studies have supported the positive associations between responsible production practices and sustainability [83], covering three dimensions of TBL [84]. In sum, responsible production is a feasible initiative to achieve sustainability based on TBL from the producer's perspective.

Considering that the positive change to sustainability is an essential attribute of responsible production and that numerous studies have discussed the effects of responsible production practices on sustainability, we aim to systematically analyze the position of responsible production for sustainability in the literature. Based on the search terms conducted in concept analysis, we add the search terms related to sustainability with the "title, abstract, keywords" used for searching. Following [85,86], the search terms of sustainability are "sustainable" OR "sustainability" OR "green" OR "outcome ${ }^{* \prime}$ OR "performance" OR "benefit*" OR "advantage" OR "consequence*" OR "economic "financial" OR "return" OR "profit", which was executed on 10 January 2021 in Scopus.

\subsection{Literature Selection}

The literature selection process needs to be objective and replicable to deliver meaningful analytic results. We followed four steps to identify literature, screen literature through title and keyword review, select eligible papers based on an abstract review, and summarize included records [87]. Figure 2 presents the whole process of literature selection. In the initial search, 4210 articles were found. The commonly used selection criteria are as follows [88]: (1) articles written in non-English language were excluded; (2) conference proceedings, book series, books, and trade journals were excluded, and journal articles remain; (3) review papers were removed, articles and conference papers were kept; (4) duplicated articles were excluded. After a series of inclusion/exclusion procedures, 2645 journal articles were selected. To identify articles more relevant for review, we reviewed the titles and keywords to pinpoint the related literature. Then, we deleted 927 articles and kept 1718 articles for their eligibility. Articles were excluded that did not meet the following two conditions: production-oriented practices and producer-focused responsibility. Finally, 
we reviewed all the abstracts to exclude irrelevant papers about responsible production for sustainability. Thus, we selected 518 articles for further review.
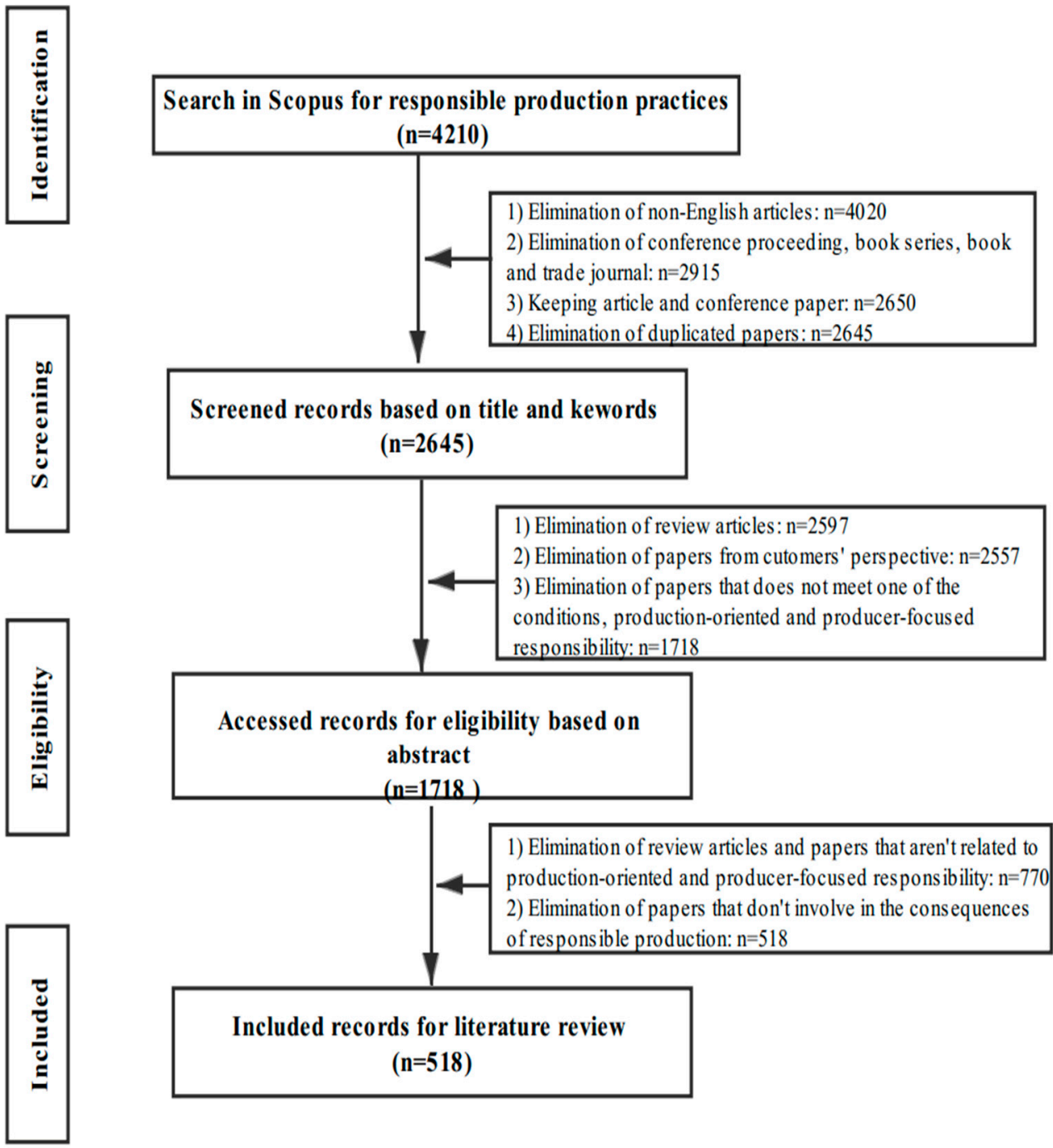

Figure 2. Selection processes of included articles.

\subsection{Descriptive Analysis}

Figure 3 depicts the number of selected articles per year. In the first two decades ranging from 1982 to 2001, nine articles were published. The number of publications slightly increases since 2002, when a conference "Corporate Sustainability Conference 2002: The Impact of CSR on Management Disciplines" was held [89]. In addition, EPR was introduced as a policy in 2001, highlighting the producer's responsibilities in mitigating the adverse impact on the environment at the post-consumption stage [3]. Considering that publication takes time, the main research period can be focused after 2002. In the period between 2003 and 2011, the number of articles increased slowly. Notably, the number of publications has remarkably increased since 2012. Moreover, the number of articles in the recent five years has accounted for more than two-thirds of the selected articles. One possible reason is that the "2030 Agenda" toward sustainable development mentions a crucial issue: responsible consumption and production (SDG 12) in 2015 [6]. Overall, responsible production for sustainability has gradually gained growing interest among scholars. 


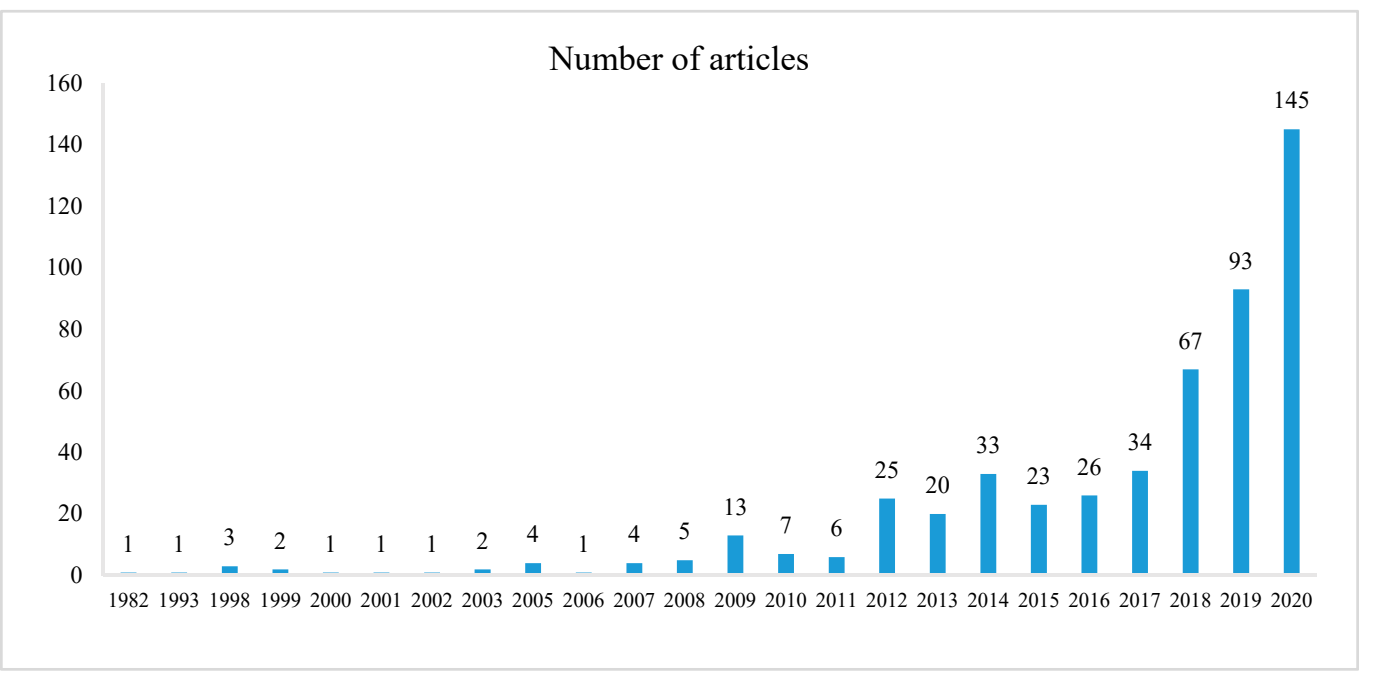

Figure 3. Number of articles per year.

Table 3 shows the top 10 journals that published articles about responsible production for sustainability. These ten journals published 197 of the articles, accounting for almost $40 \%$ of the total publications. The Journal of Cleaner Production (Impact Factor (IF) 2019: 7.246) and Sustainability (IF 2019: 2.576) have respectively published 47 articles, ranking in the first position. There are several special issues in the Journal of Cleaner Production that are relevant to this topic. For example, "Sustainable consumption and production-Research, experience, and development" in volume 138, Part 2, 2016 [90] and "Making, Buying and Collaborating for More Sustainable Production and Consumption" in volume 155, Part 2, 2017 [91] highlight the importance of sustainable production. In addition, as a journal of environmental, economic, and social sustainability of human beings, Sustainability receives a great number of articles related to responsible production for sustainability. Moreover, The International Journal of Production Economics (IF 2019: 5.134) with 20 articles follows as the third most influential journal in this field. Regarding the high IF performance and citations of these journals, the quality of selected articles allows our follow-up analysis. In addition, these top 10 journals are prominent in publishing papers about responsible production for sustainability, which is consistent with previous literature review studying sustainable practices [21]. It validates the relevancy of the selected articles and indicates that researchers published their works in professional journals [77]. In general, these journals are categorized into Environmental Sciences, Operations Research \& Management Science, Management, and Business, indicating that interdisciplinary knowledge is helpful for this line of research.

\subsection{Authorship, Citation, and Keyword Analyses}

\subsubsection{Authorship Analysis}

To identify the most productive authors who study responsible production for sustainability, we outline the top 10 authors with the most publications, as shown in Table 4. Wang $\mathrm{Z}$ has published six articles relevant to responsible production for sustainability, ranking first. Lai K.H has five publications that are cited by 188 articles, who is the second productive scholar in this field with a high h-index of 71. However, many scholars have published less than five articles on this research area. These phenomena reveal that no author is particularly prominent in this field. A possible explanation is that this topic is in its nascent stages, as responsible production is emphasized when SDG 12 was first proposed in September 2015. Moreover, according to the total link strength, highly productive scholars tend to seek academic cooperation. It demonstrates that research collaboration is helpful for academic productivity [92]. 
Table 3. Top 10 journals in terms of the number of selected articles.

\begin{tabular}{|c|c|c|c|c|c|}
\hline Journal & $\begin{array}{c}\text { Number of } \\
\text { Articles }\end{array}$ & Citations & $\begin{array}{c}\text { Impact Factor } \\
\text { (2019) }\end{array}$ & Category & Publisher \\
\hline $\begin{array}{l}\text { Journal of Cleaner } \\
\text { Production }\end{array}$ & 47 & 1572 & 7.246 & Environmental Science & Elsevier \\
\hline $\begin{array}{l}\text { Sustainability } \\
\text { International }\end{array}$ & 47 & 328 & 2.576 & Environmental Science & MDPI \\
\hline $\begin{array}{l}\text { Journal of } \\
\text { Production } \\
\text { Economics }\end{array}$ & 20 & 1026 & 5.134 & $\begin{array}{l}\text { Operations Research \& } \\
\text { Management Science }\end{array}$ & Elsevier \\
\hline $\begin{array}{c}\text { Corporate Social } \\
\text { Responsibility and } \\
\text { Environmental } \\
\text { Management }\end{array}$ & 17 & 286 & 4.542 & Business & Springer \\
\hline $\begin{array}{c}\text { Social Responsibility } \\
\text { Journal }\end{array}$ & 17 & 195 & / & Management & Emerald \\
\hline $\begin{array}{c}\text { Journal of Business } \\
\text { Ethics }\end{array}$ & 16 & 1049 & 4.141 & Business & $\begin{array}{c}\text { John Wiley \& Sons } \\
\text { Inc }\end{array}$ \\
\hline $\begin{array}{c}\text { International } \\
\text { Journal of } \\
\text { Production Research }\end{array}$ & 10 & 341 & 4.577 & $\begin{array}{l}\text { Operations Research \& } \\
\text { Management Science }\end{array}$ & Taylor \& Francis \\
\hline $\begin{array}{l}\text { Business Strategy } \\
\text { and the Environment }\end{array}$ & 9 & 74 & 5.483 & Business & $\begin{array}{c}\text { John Wiley \& Sons } \\
\text { Inc }\end{array}$ \\
\hline $\begin{array}{c}\text { Production and } \\
\text { Operations } \\
\text { Management }\end{array}$ & 8 & 337 & 2.59 & $\begin{array}{l}\text { Operations Research \& } \\
\text { Management Science }\end{array}$ & Elsevier \\
\hline $\begin{array}{c}\text { Journal of Business } \\
\text { Research }\end{array}$ & 6 & 744 & 4.874 & Business & $\begin{array}{c}\text { John Wiley \& Sons } \\
\text { Inc }\end{array}$ \\
\hline
\end{tabular}

Table 4. Top 10 authors with the most publications.

\begin{tabular}{|c|c|c|c|c|c|c|}
\hline Author & Publications & Citations & $\begin{array}{l}\text { Total Link } \\
\text { Strength }\end{array}$ & $\begin{array}{c}\text { H-Index } \\
\text { (Google Scholar) }\end{array}$ & Organizations & Countries/Regions \\
\hline Wang, Z. & 6 & 178 & 20 & 9 & $\begin{array}{c}\text { Clark University } \\
\text { Hong Kong }\end{array}$ & United States \\
\hline Lai, K.H. & 5 & 188 & 14 & 71 & $\begin{array}{l}\text { Polytechnic } \\
\text { University } \\
\text { Hong Kong }\end{array}$ & Hong Kong \\
\hline Cheng, T.C.E. & 4 & 73 & 9 & 96 & $\begin{array}{l}\text { Polytechnic } \\
\text { University }\end{array}$ & Hong Kong \\
\hline Lau, A.K.W. & 4 & 47 & 9 & 22 & $\begin{array}{l}\text { Kyung Hee } \\
\text { University }\end{array}$ & South Korea \\
\hline Liu, Z. & 4 & 14 & 17 & 11 & $\begin{array}{c}\text { Anhui Polytechnic } \\
\text { University }\end{array}$ & Chinese mainland \\
\hline Abbas, J. & 4 & 66 & 12 & 9 & Iqra University & Pakistan \\
\hline Liu, C. & 4 & 98 & 17 & 13 & $\begin{array}{l}\text { The University of } \\
\text { Nottingham } \\
\text { (Ningbo) }\end{array}$ & Chinese mainland \\
\hline Lee, $\mathrm{S}$. & 3 & 199 & 4 & 37 & $\begin{array}{l}\text { The Pennsylvania } \\
\text { State University }\end{array}$ & United States \\
\hline Thai, V.V. & 3 & 69 & 5 & 29 & $\begin{array}{l}\text { RMIT University } \\
\text { Hong Kong }\end{array}$ & Austrilia \\
\hline Lee, P.K.C & 3 & 42 & 7 & 18 & $\begin{array}{l}\text { Polytechnic } \\
\text { University }\end{array}$ & Hong Kong \\
\hline
\end{tabular}

Note: Total link strength represents the total number of an author's research collaboration with other scholars.

Table 5 presents the top 10 affiliated institutions with most publications contributing to the studies on responsible production for sustainability. The Hong Kong Polytechnic University ranks first for its prominence with 17 publications that are cited by 362 articles, 
followed by the University of Nottingham with seven publications. Noteworthy, three out of the top 10 authors, namely Lai, K.H., Cheng, T.C.E., and Lee, P.K.C. are from The Hong Kong Polytechnic University. In addition, Universiti Sains Malaysia, Universiti Utara Malaysia, and Tamkang University are the third most productive organizations with six publications. The results indicate that responsible production has aroused sparkling attention from scholars all around the world. Nowadays, many scholars are involved in studying this topic but are not productive on a personal basis. Especially in Asia, a large number of academic researchers devote themselves in studying responsible production for sustainability.

Table 5. Top 10 organizations with most publications.

\begin{tabular}{|c|c|c|c|c|}
\hline Organizations & Researchers & Publications & Citations & Regions \\
\hline $\begin{array}{l}\text { Hong Kong Polytechnic } \\
\text { University }\end{array}$ & $\begin{array}{c}\text { Lai, K.H., Cheng, T.C.E., Lee, } \\
\text { P.K.C., Yang, Y., Choi, T.M., Yeung, } \\
\text { A.C.L., Wong, C.W.Y, etc. } \\
\text { Wang, Z., Matousek, R., Liu, C., }\end{array}$ & 17 & 362 & Hong Kong \\
\hline University of Nottingham & $\begin{array}{l}\text { Wu, L., Pawar, K.S., Chapple, W., } \\
\text { Kuk, G., Hung, W.T., etc. }\end{array}$ & 7 & 133 & United Kingdom \\
\hline Universiti Sains Malaysia & $\begin{array}{l}\text { Krishnan, M., Ahmad, J., Yaacob, } \\
\text { Z., Teh, S.Y., etc. } \\
\text { Gorondutse, A.H., Udin, Z.M., }\end{array}$ & 6 & 87 & Malaysia \\
\hline Universiti Utara Malaysia & $\begin{array}{c}\text { Ahmad, R., Rahman, R.A., Anuar, } \\
\text { H.M., etc }\end{array}$ & 6 & 46 & Malaysia \\
\hline Tamkang University & $\begin{array}{l}\text { Huang, C.-M., Liao, T.-H., Hsieh, } \\
\text { Y.-H., Kuo, L., Chen, V.Y.-J., etc. }\end{array}$ & 6 & 173 & Taiwan \\
\hline RMIT University & $\begin{array}{l}\text { Thai, V.V., Yadlapalli, A., Rahman, } \\
\text { S., Huang, X., As-Saber, S., etc. }\end{array}$ & 5 & 86 & Australia \\
\hline $\begin{array}{l}\text { Iran University of Science } \\
\text { and Technology }\end{array}$ & $\begin{array}{c}\text { Hosseini-Motlagh, S.-M., Nami, N., } \\
\text { Farshadfar, Z., Ranjbar, Y., Sahebi, } \\
\text { H., etc. }\end{array}$ & 5 & 8 & Iran \\
\hline Yonsei University & $\begin{array}{l}\text { Sarkar, B., Phillips, J., Woo, H., Son, } \\
\text { D., Kim, S., Park, H., Jeong, B., etc. }\end{array}$ & 5 & 18 & South Korea \\
\hline Kyung Hee University & $\begin{array}{c}\text { Lau, A.K.W., Jung, S., Lee, S., and } \\
\text { Kang, K.H. }\end{array}$ & 4 & 111 & South Korea \\
\hline $\begin{array}{l}\text { Massachusetts Institute of } \\
\text { Technology }\end{array}$ & $\begin{array}{c}\text { Kazemi, N., Zheng, Y., Kraft, T., } \\
\text { etc. }\end{array}$ & 4 & 151 & United States \\
\hline
\end{tabular}

\subsubsection{Citation Analysis}

Citation analysis can identify a large number of bibliographic publications with cited references in a research field, which helps depict research communities and research streams [93]. The citation linkage between an article and references reflects the relevance of works in discussing a specific topic. A reference is more highly cited by many publications in a particular field, which means that this reference has a greater possibility of narrating the same topic as these publications. Thus, citation analysis is suitable for portraying research domains implied in selected articles [94].

Table 6 presents the top 20 cited references of all included papers with the most citations. These references were published between 1979 and 2010, including review papers, conceptual papers, methodological papers, and empirical papers. In terms of journals, cited references from management disciplines account for the majority. The Academy of Management Review, Academy and Management Journal, and Strategic Management Journal are three major journals publishing the most cited references. Moreover, these journals are prestigious, which is conducive to the reliability of the subsequent analysis. Local citation represents the cited frequency of a reference by 518 articles, while global citation refers to citation frequency of references cited by articles in the Google Scholar database [21]. The most cited reference by selected articles was published in Organization Studies, where Orlitzky et al. adopted a meta-analysis of 52 studies to examine the corporate 
social performance-corporate financial performance (CSP-CFP) link [95]. Noteworthy, 14 out of 20 studies have investigated the CSP-CFP relationship, supporting bidirectional causality between CSP and CFP. Furthermore, corporate abilities and industry growth are the essential factors moderating the CSP-CFP link [96], while firm reputation and customer satisfaction are mediators in this link [97]. Moreover, Carroll has at least four out of the 20 most cited references, who proposed a three-dimensional conceptual model of corporate performance [98] and the pyramid of CSR [99], laying a theoretical foundation for follow-up research on responsible production.

Table 6. Top 20 cited references of selected articles with the most citations.

\begin{tabular}{|c|c|c|c|c|c|}
\hline Cited References & Authors & Year & Journal & Local Citation & Global Citation \\
\hline [95] & $\begin{array}{l}\text { Orlitzky, Schmidt } \\
\text { et al. }\end{array}$ & 2003 & Organization Studies & 38 & 8066 \\
\hline [100] & $\begin{array}{c}\text { McWilliams and } \\
\text { Siegel }\end{array}$ & 2000 & $\begin{array}{c}\text { Strategic Management } \\
\text { Journal }\end{array}$ & 25 & 4246 \\
\hline [98] & Carroll & 1979 & $\begin{array}{c}\text { Academy of } \\
\text { Management Review }\end{array}$ & 22 & 15,127 \\
\hline [101] & $\begin{array}{l}\text { Margolis and } \\
\text { Walsh }\end{array}$ & 2003 & $\begin{array}{c}\text { Administrative Science } \\
\text { Quarterly }\end{array}$ & 21 & 5821 \\
\hline [102] & $\begin{array}{l}\text { Fornell and } \\
\text { Larcker }\end{array}$ & 1981 & $\begin{array}{c}\text { Journal of Marketing } \\
\text { Research }\end{array}$ & 20 & 67,619 \\
\hline [99] & Carroll & 1991 & Business Horizons & 20 & 12,225 \\
\hline [103] & $\begin{array}{l}\text { Waddock and } \\
\text { Graves }\end{array}$ & 1997 & $\begin{array}{c}\text { Strategic Management } \\
\text { Journal }\end{array}$ & 19 & 7531 \\
\hline [104] & Russo and Fouts & 1997 & $\begin{array}{c}\text { Academy of } \\
\text { Management Journal }\end{array}$ & 19 & 5263 \\
\hline [105] & Hart & 1995 & $\begin{array}{c}\text { Academy of } \\
\text { Management Review }\end{array}$ & 18 & 7062 \\
\hline [106] & $\begin{array}{c}\text { McWilliams and } \\
\text { Siegel }\end{array}$ & 2001 & $\begin{array}{c}\text { Academy of } \\
\text { Management Review }\end{array}$ & 18 & 8025 \\
\hline [107] & $\begin{array}{c}\text { Sen and } \\
\text { Bhattacharya }\end{array}$ & 2001 & $\begin{array}{c}\text { Journal of Marketing } \\
\text { Research }\end{array}$ & 16 & 5560 \\
\hline [97] & $\begin{array}{c}\text { Luo and } \\
\text { Bhattacharya }\end{array}$ & 2006 & Journal of Marketing & 15 & 3451 \\
\hline [108] & $\begin{array}{c}\text { McGuire, } \\
\text { Sundgren et al. }\end{array}$ & 1988 & $\begin{array}{c}\text { Academy of } \\
\text { Management Journal }\end{array}$ & 15 & 4031 \\
\hline [109] & $\begin{array}{l}\text { Turban and } \\
\text { Greening }\end{array}$ & 1997 & $\begin{array}{c}\text { Academy of } \\
\text { Management Journal }\end{array}$ & 14 & 3809 \\
\hline [110] & $\begin{array}{l}\text { Carroll and } \\
\text { Shabana }\end{array}$ & 2010 & $\begin{array}{l}\text { International Journal of } \\
\text { Management Reviews }\end{array}$ & 13 & 4060 \\
\hline [111] & $\begin{array}{c}\text { Aupperle, Carroll } \\
\text { et al. }\end{array}$ & 1985 & $\begin{array}{c}\text { Academy of } \\
\text { Management Journal }\end{array}$ & 13 & 3648 \\
\hline [112] & $\begin{array}{l}\text { Klassen and } \\
\text { McLaughlin }\end{array}$ & 1996 & Management Science & 13 & 3080 \\
\hline [96] & $\begin{array}{c}\text { Hull and } \\
\text { Rothenberg }\end{array}$ & 2008 & $\begin{array}{c}\text { Strategic Management } \\
\text { Journal } \\
\text { Corporate Social }\end{array}$ & 12 & 902 \\
\hline [113] & Dahlsrud & 2008 & $\begin{array}{c}\text { Responsibility and } \\
\text { Environmental } \\
\text { Management }\end{array}$ & 12 & 4953 \\
\hline [114] & Campbell & 2007 & $\begin{array}{c}\text { Academy of } \\
\text { Management Review }\end{array}$ & 10 & 4401 \\
\hline
\end{tabular}

\subsubsection{Keyword Analysis}

Keyword analysis is an effective and time-saving way to pinpoint the most popular research topics extracted from publications [115]. Table 7 presents the top 30 keywords in terms of occurrence frequency. According to keyword frequency, corporate responsibility (e.g., corporate social responsibility and social responsibility) and sustainability (e.g., 
sustainable development and sustainability) are two major research streams that align with the search terms. Given that responsible production for sustainability, research topics cover the three dimensions of TBL, including economic (e.g., "financial performance", "profitability", and "sales"), social (e.g., "economic and social effects"), and environmental (e.g., "environmental performance") aspects. In addition, it is shown that the relationship between responsible production practices and financial performance attracted widespread concern, becoming a popular research topic. Moreover, manufacturing (e.g., "manufacturer" and "manufacturing") and supply chain (e.g., "supply chain management" and "supply chains") are of particular interest to scholars in studying responsible production. This result indicates that responsible production requires not only internal management but also external coordination. Notably, "China" is a conspicuous keyword, indicating that China may be a targeted sample to observe. It further demonstrates that responsible production is of great importance to achieve sustainability in developing countries. In addition, empirical analysis (e.g., "structural equation modeling" and "empirical analysis") is the popular approach. In brief, this research encourages a diversity of research methods to help comprehensively assess responsible production practices.

Table 7. Top 30 keywords in terms of occurrence frequency.

\begin{tabular}{|c|c|c|c|c|c|}
\hline Keywords & Freq & Keywords & Freq & Keywords & Freq \\
\hline CSR & 393 & China & 32 & $\begin{array}{l}\text { Organizational } \\
\text { Performance }\end{array}$ & 15 \\
\hline $\begin{array}{l}\text { Sustainable } \\
\text { Develop- } \\
\text { ment }\end{array}$ & 77 & $\begin{array}{c}\text { Firm } \\
\text { Performance }\end{array}$ & 20 & Sales & 15 \\
\hline $\begin{array}{l}\text { Social Re- } \\
\text { sponsibility }\end{array}$ & 72 & Finance & 19 & $\begin{array}{l}\text { Environmental } \\
\text { Impact }\end{array}$ & 14 \\
\hline Sustainability & 63 & $\begin{array}{l}\text { Stakeholder } \\
\text { Theory }\end{array}$ & 19 & $\begin{array}{c}\text { Empirical } \\
\text { Analysis }\end{array}$ & 14 \\
\hline $\begin{array}{c}\text { Economic } \\
\text { and Social } \\
\text { Effects }\end{array}$ & 43 & Profitability & 18 & $\begin{array}{c}\text { Industrial } \\
\text { Performance }\end{array}$ & 14 \\
\hline $\begin{array}{c}\text { Financial } \\
\text { Performance }\end{array}$ & 41 & $\begin{array}{l}\text { Environmental } \\
\text { Performance }\end{array}$ & 16 & $\begin{array}{l}\text { Competitive } \\
\text { Advantage }\end{array}$ & 12 \\
\hline $\begin{array}{l}\text { Supply Chain } \\
\text { Management }\end{array}$ & 39 & $\begin{array}{l}\text { Environmental } \\
\text { Protection }\end{array}$ & 16 & Firm Value & 12 \\
\hline $\begin{array}{l}\text { Environmental } \\
\text { Management }\end{array}$ & 37 & $\begin{array}{l}\text { Extended } \\
\text { Producer Re- } \\
\text { sponsibility }\end{array}$ & 16 & Innovation & 12 \\
\hline Manufacturing & 35 & $\begin{array}{c}\text { Performance } \\
\text { Assessment }\end{array}$ & 16 & Game Theory & 14 \\
\hline $\begin{array}{l}\text { Supply } \\
\text { Chains }\end{array}$ & 33 & Competition & 15 & $\begin{array}{l}\text { Structural } \\
\text { Equation } \\
\text { Modeling }\end{array}$ & 14 \\
\hline
\end{tabular}

\subsection{Network Analysis}

\subsubsection{Co-Citation Analysis}

Co-citation analysis maps an overview of the structure of a special field, identifying several clusters of related publications [79]. These clusters represent different research streams, and a cluster comprises the closely related papers linked to a scientific topic. To select high-quality papers for a co-citation analysis, we included references cited at least six times by 518 publications in the dataset. A total of 99 references meet this condition, forming five clusters with representative references, as illustrated in Table 8. Through a review of these articles, we identify five research topics representing various clusters. Cluster 1 depicts the theoretical and conceptual development of responsible production for sustainability. Hart proposed a natural-resource-based view and suggested that pollution prevention, product stewardship, and sustainable development are strategic capabilities in 
environmental responsibility that contribute to competitive advantage (e.g., lower costs and preempt competitors) and social legitimacy (e.g., stakeholder integration, public scrutiny, and technology cooperation) [105]. Cluster 2 is about evaluating the financial performance effects of responsible production. For example, investment in research and development (R\&D) is a crucial factor determining the relationship between responsible production practices and financial performance [100]. Cluster 3 elaborates the definition and measurement of responsible production-related concepts. Carroll put forward a three-dimensional model of corporate performance, incorporating social issues, social responsibility, and social responsiveness [98]. In addition, Wood summarized how to measure corporate social performance [116]. Cluster 4 discusses performance assessment on responsible production practices from a stakeholder perspective. Evidence has shown that responsible production can achieve stakeholder value [117] and customer satisfaction [97]. Cluster 5 sheds light on the challenges and strategic implications of studying responsible production strategies. McWilliams et al. pointed out several limitations, such as the lack of detailed performance assessment to measure the financial impacts of responsible production practices and the neglect of the mediation process between responsible production practices (e.g., CFP) and financial performance [118]. These five clusters may depict the research development of responsible production from theoretical construction and variable measurements to performance assessment and literature reflection.

Table 8. Five clusters of cited references.

\section{Clusters}

\section{Representive References}

A natural-resource-based view of the firm

From a literature review to a conceptual framework for sustainable supply chain management

Cluster 1: Theoretical and conceptual development A resource-based view of the firm

A contingent resource-based view of proactive corporate environmental strategy

Corporate social and financial performance: a meta-analysis

Corporate social responsibility and financial performance: correlation or misspecification

Corporate social responsibility and firm financial performance

A three-dimensional conceptual model of corporate performance

Cluster 3: Definition and measurement

Corporate social responsibility: Evolution of a definitional construct

Corporate social performance revisited

Proactive environmental strategies: A stakeholder management perspective

The relationship between corporate social responsibility and shareholder value: An empirical test of the risk management hypothesis

Toward a theory of stakeholder identification and salience:

Defining the principle of who and what really counts

Corporate social responsibility: Strategic implications

The challenge of measuring financial impacts from investments in corporate social performance

Cluster 5: Challenges and implications

\subsubsection{Keyword Co-Occurrence Analysis}

Keyword co-occurrence analysis is one of the crucial bibliometric analyses to examine salient research topics [119]. We adopt VOSviewer to conduct clustering analysis based on keyword co-occurrence. Author keywords and index keywords are the unit of analysis, and the keywords that occur more than four times are selected. Thus, 133 keywords meet the threshold. Figure 4 presents five clusters extracted from keywords. Cluster 1 indicates that optimization and supply chain management is a prominent topic when 
studying responsible production for sustainability. Especially when the extended producer responsibility policy was issued, enterprises should balance the relationship between profitability and environmental impact, making them pay more attention to supply chain coordination and internal control in the production processes. Clusters 2, 3, and 5 depict a multidimensional performance assessment of responsible production practices, including financial, social, and environmental aspects. Sustainability is considered as sustainable development toward the TBL, highlighting environmental friendliness, social harmony, and economic improvement [120]. From a holistic perspective, the overall performance assessment on sustainability is examined, as shown in Cluster 4. In terms of the keyword cooccurrence network, massive studies focus on an economic and environmental assessment of responsible production practices, while less attention is paid to social assessment as well as TBL assessment in evaluating responsible production performance. Future research can extend to some issues about social impact that responsible production practices may bring, such as human safety and employment.

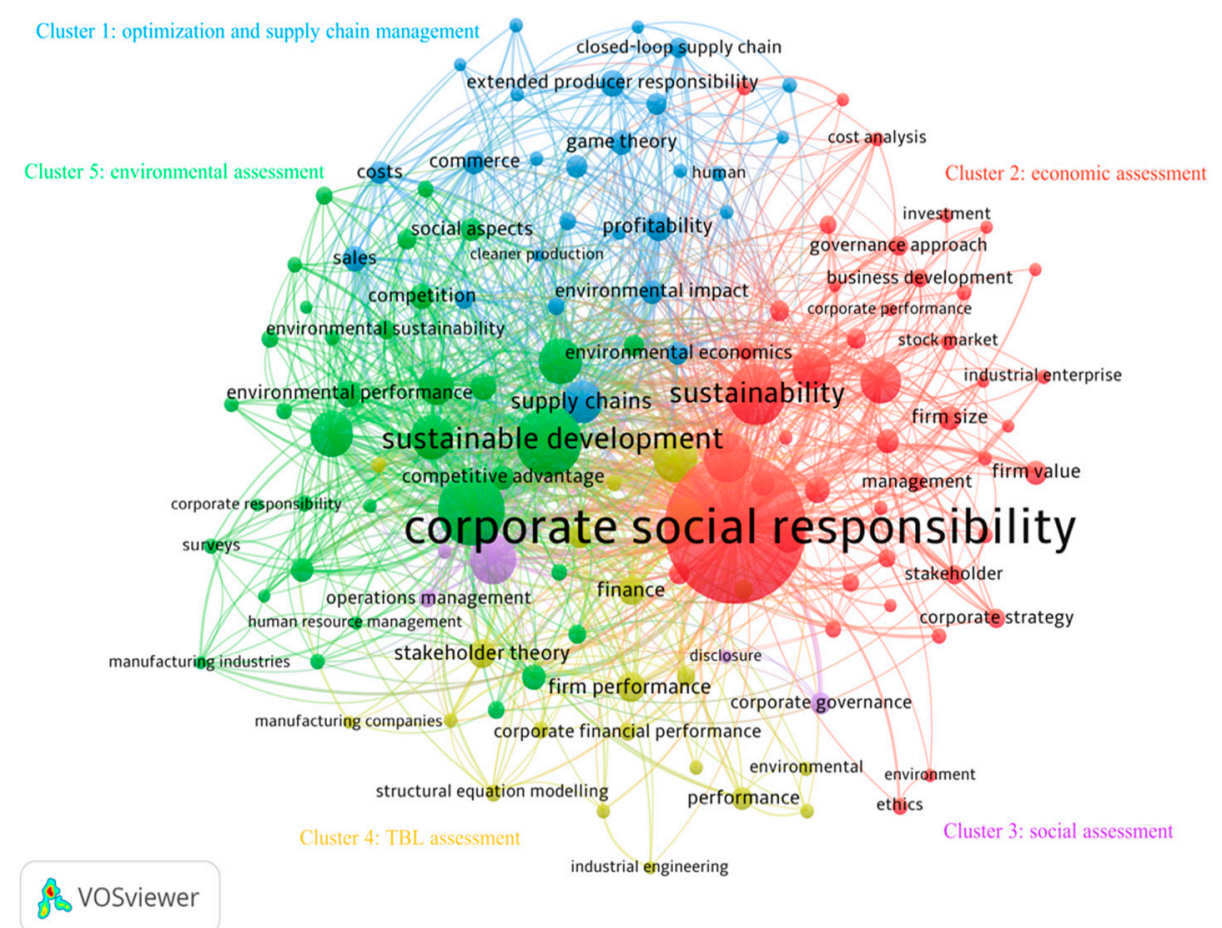

Figure 4. Keyword co-occurrence network.

\subsubsection{Country Collaboration Analysis}

As a pattern of intense interaction, research collaboration has been emphasized, as knowledge exchange from different backgrounds is helpful for academic success [92]. Table 9 presents the top 10 countries/regions with the most publications in collaboration with other regions. China (Chinese mainland, Hong Kong, and Taiwan) has achieved outstanding performance in publication volume; especially, the Chinese mainland has built intense interaction and established research collaboration with other regions 70 times. Moreover, the United States has the most citations, ranking first in terms of publication quality. Nevertheless, according to citations per publication, Australia and the United Kingdom have published high-quality articles, performing well in studying responsible production. Notably, the United Kingdom is more proactive in research collaboration because this country has the average link per publication of 1.04. On average, they work with at least one author from different regions for a publication. The results indicate that research collaboration is conducive to the quantity and quality of publications. 
Table 9. Top 10 countries in terms of publications.

\begin{tabular}{|c|c|c|c|c|c|c|}
\hline Country/Region & Publications & $\begin{array}{c}\text { Average } \\
\text { Publication Year }\end{array}$ & Citations & $\begin{array}{l}\text { Citations per } \\
\text { Publication }\end{array}$ & $\begin{array}{c}\text { Total Link } \\
\text { Strength }\end{array}$ & $\begin{array}{c}\text { Average Link } \\
\text { per Publication }\end{array}$ \\
\hline United States & 101 & 2015 & 2739 & 27.12 & 55 & 0.54 \\
\hline $\begin{array}{l}\text { Chinese } \\
\text { mainland }\end{array}$ & 99 & 2018 & 1139 & 11.51 & 70 & 0.71 \\
\hline United Kindom & 51 & 2015 & 1686 & 33.06 & 53 & 1.04 \\
\hline Taiwan & 39 & 2016 & 598 & 15.33 & 15 & 0.38 \\
\hline South Korea & 28 & 2017 & 439 & 15.68 & 22 & 0.79 \\
\hline India & 28 & 2017 & 262 & 9.36 & 11 & 0.39 \\
\hline Malaysia & 27 & 2016 & 832 & 30.81 & 18 & 0.67 \\
\hline Australia & 26 & 2016 & 933 & 35.88 & 19 & 0.73 \\
\hline Italy & 22 & 2017 & 431 & 19.59 & 4 & 0.18 \\
\hline Spain & 21 & 2916 & 641 & 30.52 & 14 & 0.67 \\
\hline
\end{tabular}

Note: Average link per publication is the ratio of total link strength to the number of publications.

Figure 5 presents a co-authorship network based on countries/regions. Countries with lighter color are those who publish more recent articles on average. Considering average publication year, Pakistan, Vietnam, and Poland are the emerging countries that have come recently into studying responsible production research, as they published related articles in 2019 on average. Moreover, the Chinese mainland follows with active research on this topic in recent years, as their scholars published related research around 2018. Notably, the Chinese mainland has achieved the status of the second most productive region with 99 publications. These findings indicate that responsible production for sustainability has recently attracted widespread attention among scholars, especially in developing countries.

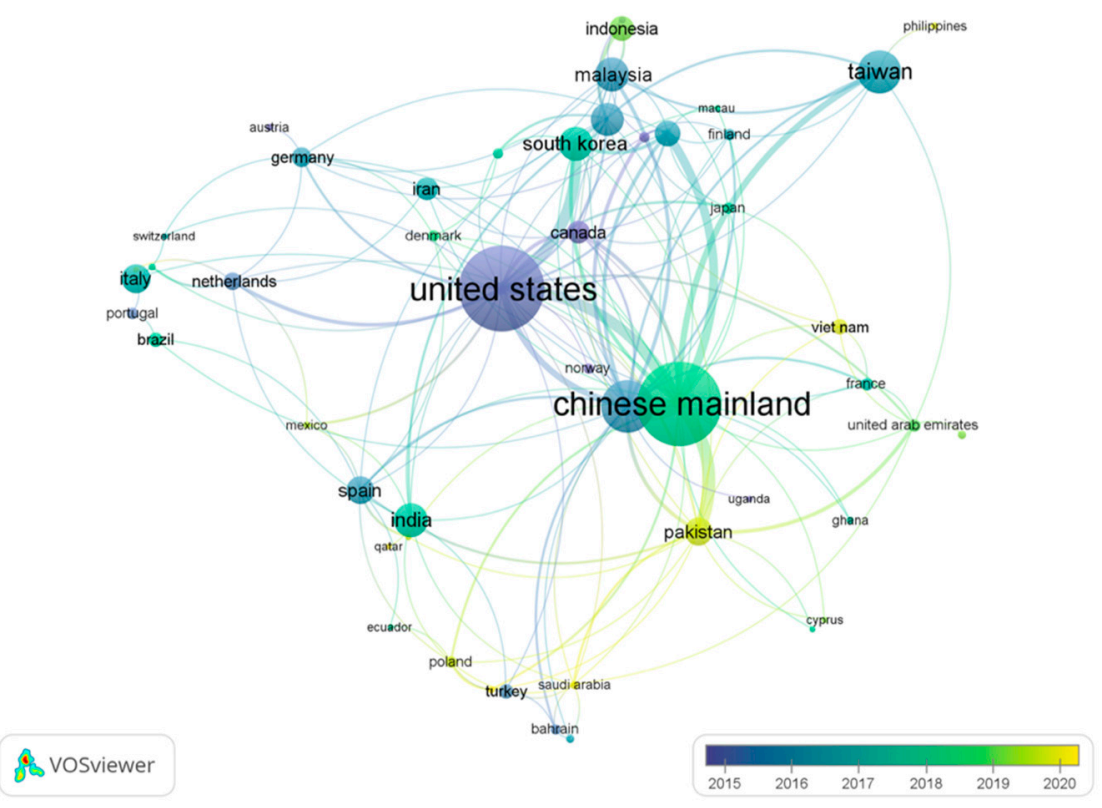

Figure 5. Country collaboration network.

\subsubsection{Term Co-Occurrence Analysis}

To prevent keyword co-occurrence analysis from missing valuable information, we further consider title and abstract to conduct term co-occurrence analysis. Title and abstract are the same in importance as keywords to capture the core content of an article [21]. The terms from title and abstract that occur more than nine times are selected, and 300 terms meet the threshold. Table 10 outlines the top 20 terms according to term relevance. The most relevant term is "extender producer responsibility" with the term relevance of 6.81, which is followed by "return on assets" and "corporate social performance". Moreover, 
as an authoritative criterion underpinning corporate responsibility, the environmental, social, and governance (ESG) index is relevant to the topic on responsible production [121]. Additionally, terms regarding financial performance account for a quarter of the top 20 terms, such as "return on assets", "revenue", and "profit". It indicates that the concern over financial performance is salient and relevant to responsible production for sustainability.

Table 10. Top 20 terms with the most relevance.

\begin{tabular}{|c|c|c|c|c|c|}
\hline Term & Relevance & Occurrences & Term & Relevance & Occurrences \\
\hline extended & & & corporate & & \\
\hline $\begin{array}{l}\text { producer re- } \\
\text { sponsibility }\end{array}$ & 6.81 & 13 & $\begin{array}{c}\text { financial } \\
\text { performance }\end{array}$ & 2.26 & 14 \\
\hline $\begin{array}{l}\text { return on } \\
\text { assets }\end{array}$ & 3.76 & 11 & $\begin{array}{l}\text { environmental } \\
\text { impact }\end{array}$ & 2.20 & 21 \\
\hline $\begin{array}{l}\text { corporate } \\
\text { social } \\
\text { performance }\end{array}$ & 3.48 & 10 & manufacturer & 2.14 & 55 \\
\hline $\begin{array}{l}\text { retailer } \\
\text { environmental, }\end{array}$ & 3.34 & 20 & increase & 2.12 & 26 \\
\hline $\begin{array}{l}\text { social, } \\
\text { governance }\end{array}$ & 3.15 & 14 & mediator & 2.10 & 15 \\
\hline example & 3.14 & 20 & end & 2.10 & 12 \\
\hline revenue & 2.75 & 11 & equity & 2.06 & 15 \\
\hline situation & 2.73 & 21 & asset & 1.98 & 25 \\
\hline demand & 2.60 & 30 & profit & 1.75 & 54 \\
\hline respect & 2.26 & 10 & incentive & 1.72 & 23 \\
\hline
\end{tabular}

Note: Relevance represents the extent of the co-presence or the co-absence of a term extracted from abstract and title with other terms in a document.

Figure 6 depicts the term co-occurrence network, forming four clusters. Clusters 1 and 3 are about performance assessment, indicating the duality of responsible production practice for enterprises. One is about risk assessment (e.g., negative impact and risk), the other concerns sustainability assessment (e.g., advantage and competitiveness). Clusters 2 and 4 depict the concept of responsible production, covering two manifestations: production-based process management (e.g., product and production) and producer-based responsibility (e.g., responsibility, enterprise, organization, and employee). Although the existing literature has investigated and assessed responsible production practices, there is no mature definition of the concept of responsible production. Thus, scholars are suggested to define the concept of responsible production and develop a framework for assessing its practices by combining theoretical with practical knowledge.

\subsection{Theme Evolution Analysis}

To observe the dynamic evolution of research themes over time, we adopt Citespace to run visualization using citation bursts analysis [80]. Considering that the number of articles regarding responsible production has been growing since 2012, we aim to observe the theme evolution in terms of keywords from 2012 to 2020, which is illustrated in Figure 7. We set the selection criteria as "Usage 180", selected 200 items, and found the top 14 keywords with the strongest citation bursts. If a keyword was frequently used in a certain time period, the keyword may be regarded as a keyword with strong citation bursts [122]. Thus, citation bursts are indicators of the most active areas. At the early stage, in addition to industry, responsibility and sustainability are two salient concepts in 2012, laying the theoretical background for follow-up research. During the period from 2015 to 2018, supply chain management (SCM) and performance assessment (e.g., sale, finance, firm performance, and firm value) are the salient topics, and the focus is targeted at small- and medium-size enterprises (SME) in manufacturing industries (e.g., manufacture). Since 2018, corporate social performance and corporate sustainability have attracted academic attention without diminishing enthusiasm, highlighting the responsibility of enterprises. In summary, responsible production is an action of corporate social performance, which needs 
external (e.g., supply chain management) and internal (e.g., manufacture) coordination, aiming at achieving sustainable development. This topic focusing on producer-based responsibility in production and operations management has fascinated academic attention in recent years.

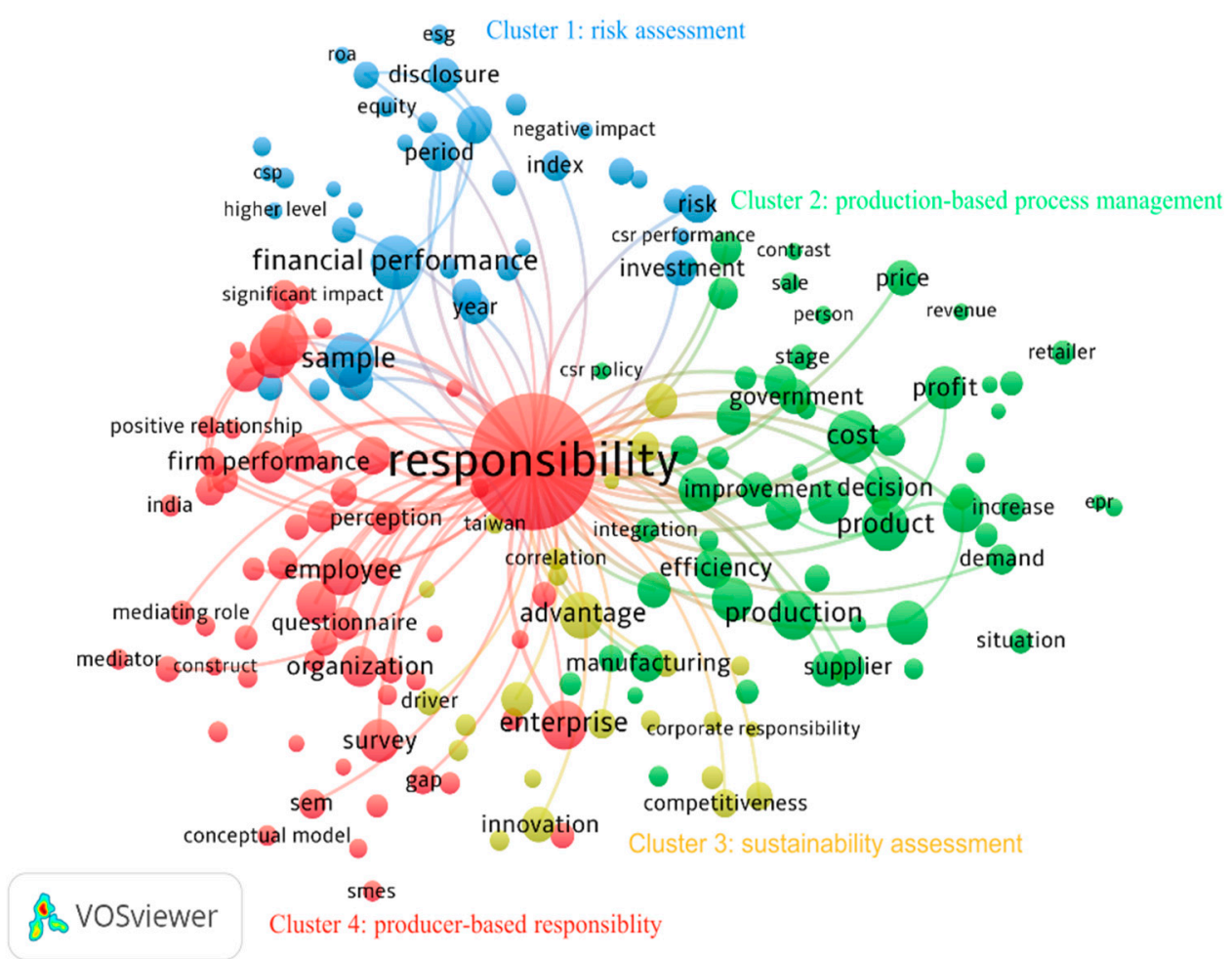

Figure 6. Term co-occurrence network.

\begin{tabular}{|c|c|c|c|c|}
\hline \multirow{2}{*}{$\begin{array}{l}\text { Keywords } \\
\text { industry }\end{array}$} & \multicolumn{3}{|c|}{ Year Strength Begin End } & \multirow[t]{2}{*}{$2012-2020$} \\
\hline & 2012 & 3.62012 & 2013 & \\
\hline social responsibility & 2012 & 3.492012 & 2016 & \\
\hline sustainability & 2012 & 2.92012 & 2015 & \\
\hline sustainable development & 2012 & 2.682012 & 2017 & \\
\hline manufacture & 2012 & 3.262014 & 2016 & \\
\hline sale & 2012 & 2.812014 & 2016 & \\
\hline supply chain management & 2012 & 3.212015 & 2016 & \\
\hline sme & 2012 & 2.372016 & 2017 & \\
\hline firm performance & 2012 & 2.832017 & 2018 & \\
\hline finance & 2012 & 2.792017 & 2018 & \\
\hline firm value & 2012 & 2.682017 & 2018 & \\
\hline $\operatorname{csr}$ & 2012 & 2.592018 & 2020 & \\
\hline corporate sustainability & 2012 & 2.472018 & 2020 & \\
\hline corporate social performanc & 2012 & 2.342018 & 2020 & \\
\hline
\end{tabular}

Figure 7. Theme evolution in terms of keywords from 2012 to 2020. 


\section{Discussion}

4.1. Findings

As one of the CSR areas, responsible production for sustainability has attracted scholars' growing attention [8]. Through a concept analysis of responsible production, we clarify this concept with the defining attributes and model/contrary cases. Based on 317 empirical studies, we also summarize the antecedents and consequences of responsible production based on previous empirical studies. Through a review of 518 articles relevant to responsible production for sustainability, we conduct a bibliometric analysis to capture research topics. First, we identify necessary information about authorship, citation, and keyword, generating a rough idea of current research. Second, we map four networks: co-citation, keyword co-occurrence, country collaboration, and term co-occurrence, to examine the research focus. Third, we depict the dynamic evolution of themes to clarify the research trends.

Responsible production for sustainability has aroused increasing interest in academia, especially in the last five years. It indicates that scholars begin to attach more importance to responsible production after SDG 12 was proposed in 2015. However, few scholars or institutions are productive on studying responsible production. The results may be attributed to the lack of a clear definition of the concept of responsible production, although CSR and SCM have been studied extensively. Different from CSR, responsible production is emphasized in production-based process management rather than social philanthropy. Relative to SCM, responsible production depicts producer-based responsibility manifesting not only in external coordination but also internal control. To define the concept of responsible production, we conduct concept analysis and summarize its four attributes: the change to sustainability, preventive initiatives, process management, and company-specific context. Moreover, we conclude that firm characteristics (e.g., corporate citizenship) and contextual factors (e.g., regulations and information technology) are the antecedents of responsible production practices adoption, which may affect customer attitude, employee behavior, firm performance (e.g., economic, environmental, and social sustainability), and other stakeholders. These findings can provide a theoretical basis for defining, disseminating, and assessing responsible production, as responsible production is one crucial goal of the SDGs valued by the United Nations.

Although responsible production for sustainability has received global concern, it has recently set off a research boom in developing countries such as the Chinese mainland, Pakistan, and Vietnam. This result is consistent with previous literature review indicating that responsible practices receive significant attention from developing countries [10,21]. With the rapid development of industrialization, developing countries face the challenge from environmental degradation and social issues. Responsible production is a feasible way to reduce these risks and achieve the sustainability toward TBL. Notably, China is one of the most conspicuous countries in this regard. On the one hand, China has cultivated many prominent scholars who are in the top 10, but it also created the most publications at the country level. On the other hand, China is of particular interest among scholars because China is a global manufacturing base to output China-made products entering international markets in recent decades and to service the global production demands. The country suffers from increasing environmental hazards, including haze weather [123], and it needs a solution to relieve the damages, particularly those caused by manufacturing operations. Moreover, the Chinese government has established the Belt and Road policy, where manufacturing enterprises are encouraged to "go out" for business opportunities and growth Responsible production can facilitate Chinese manufacturers to overcome international trade barriers, since there are stricter regulations on environmental issues in developed countries, while it is also important for them to establish a good image in developing countries [124]. Thus, the findings have research and practical implications by encouraging scholars and enterprises to understand responsible production for sustainability, especially in developing countries. 
Notably, the link between responsible production and financial performance receives significant interest among scholars. However, studies on the social dimension regarding responsible production as well as comprehensively considering three aspects of sustainability are scarce. This finding confirms the previous literature review arguing that there has been a neglect of social assessment in achieving sustainability [12]. In terms of research methodology, empirical analysis accounts for the majority, especially the use of questionnaire data. Future research can adopt the multi-methods approach and objective second-hand data as the supplement to examine the outcomes of responsible production. Evidence also has shown that extended producer responsibility is most relevant to the research topic, and ESG is a crucial index to assess responsible production. These results provide some references for studying this topic, but they also indicate that responsible production needs a more synthesized assessment framework for scholars to extend the related research.

In addition, we advance the knowledge on responsible production by uncovering the research development of the existing literature. Based on the network analysis, we find that there are five research domains discussing responsible production: (1) Theoretical and conceptual development; (2) Definition and measurement; (3) Performance assessment; (4) Optimization and supply chain management; and (5) Challenges and implications. Moreover, the result shows that producer-based responsibility is emphasized in external coordination (supply chain management) and internal control, especially for small and medium-sized enterprises in manufacturing industries. In addition, responsible production for sustainability has attracted scholarly attention in recent years. It is strategically important for enterprises to pay attention to in the production processes, which is also a prominent topic for scholars to expand this emerging research.

Moreover, we have also provided strong evidence that research collaboration, at either the author level or country level, is positively associated with the number and the quality of publications. This result confirms that academic success depends on knowledge exchange and transfer, indicating the importance of the openness in the professional network for knowledge creation [125]. To facilitate knowledge creation and the transfer of responsible production, research collaboration is an appropriate way for scholars to achieve academic success.

\subsection{Research Gaps and Suggested Directions}

Considering the booming research enthusiasm in studying the relationship between responsible production and financial performance, we identify some gaps to fill in future research. First, the existing literature lacks a clear definition, although responsible production has gradually attracted academic attention since SDG 12 was proposed. Moreover, related research on responsible production is still in its nascent stages [8]. Future research should consider defining and measuring this important concept by combining previous studies with corporate behaviors. Second, empirical studies dominate research methods, including case study and structural equation modeling, with data collected from surveys/questionnaires and interviews. However, these methodologies can suffer from either sample selection bias or common method bias. In addition, the reliability of respondents is also doubtful in terms of measurement quality. McWilliams et al. pointed out that the performance assessment of a financial aspect is relatively rough, lacking diverse and detailed indicators to measure, confining only to perception-based financial performance [118]. Considering measurement errors caused by subjective data, objective data from companies can be used as a good supplement. Specifically, responsible production practices can be extracted from corporate announcements and social media, while financial performance is obtained from annual reports, stock market, or authoritative databases (e.g., Wind, CSMAR). To better collect and process with multiple sources of evidence, we can employ a multi-method approach involving topic modeling with machine learning, event study, simulation, and company interviews to address the above issues. Third, the effect of responsible production on financial performance is a popular topic for sustainability research. Yet, scant attention is paid to mediating roles of this link [118]. It is also unclear 
on the factors causing the performance contingency. To advance knowledge on the relationship of responsible production and financial performance, it is worthwhile to examine the mediation and moderation effects on this relationship. Finally, although numerous studies have investigated the unidirectional and bidirectional association of responsible production and financial performance, the topic concerning dynamic relationship between them is under-explored. Another promising research direction is to analyze the dynamic relationship evolution by simulating the diffusion of responsible production practices among manufacturers and the evolution with financial performance. In sum, the following research questions are worthy of further investigation in extending the research on the link between responsible production and financial performance. Figure 8 provides a research framework to address these questions.

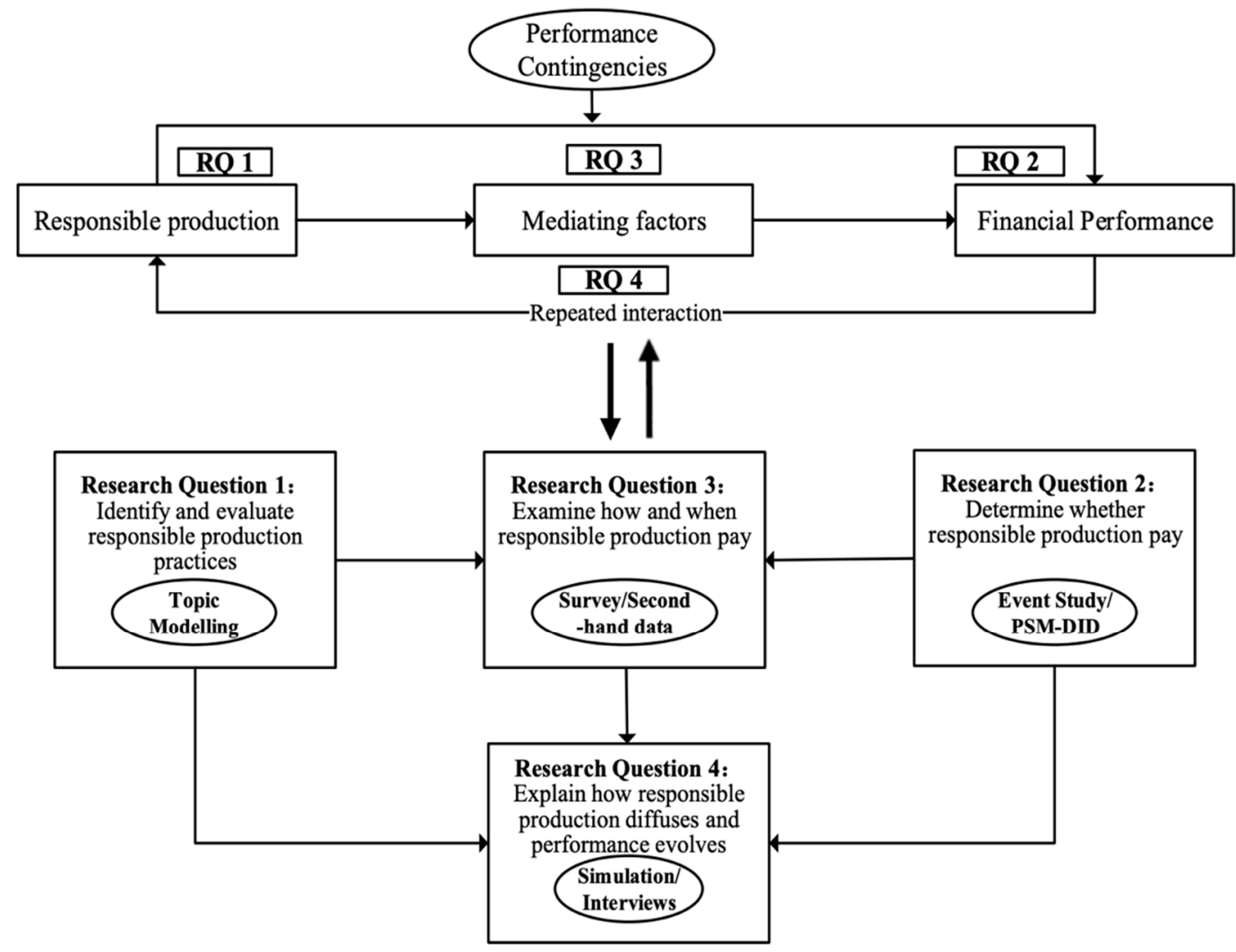

Figure 8. A research framework.

Q 1: How to evaluate responsible production practices in different manufacturing and service operations contexts?

$\mathrm{Q}$ 2: Does responsible production pay?

Q 3: What are contingencies influencing the relationship between responsible production and financial performance?

Q 4: How does the responsible production and financial performance evolve under these performance contingency factors?

\subsection{Managerial and Policy Implications}

Ours is the first study providing a concept analysis and bibliometric review of responsible production for sustainability. For the former, we clarify the attributes, antecedents, and consequences of responsible production. The analysis provides managerial insights on the definition of responsible production, laying a theoretical basis for enterprises in production and operations management. The attributes identified are also helpful for policy actions to diffuse responsible production practices. The latter identifies different research domains of responsible production for sustainability with a bibliometric review. It 
is desirable for firms to value "ESG" and "extended producer responsibility" as the crucial aspects of developing the implementation framework of responsible production. Especially in the manufacturing sector, firms should pay attention to responsible production because corporate sustainability is closely associated with responsible production in the long run. For example, it is highly desirable for enterprises to cultivate a responsible environment to educate and train employees for responsible production. The total involvement of staff to monitor each stage of the value chain covering supplier management and product design is helpful for responsible production practices diffusion. As evaluating of the performance of responsible production is crucial for its success, policymakers should set a benchmark performance standard to facilitate the process, which can create a win-win environment by addressing the needs of different stakeholders through motivating firms to adopt responsible practices proactively.

\section{Conclusions}

With both qualitative (concept analysis) and quantitative (bibliometric review) analyses, we clarify the defining attributes and capture the antecedents and consequences of responsible production. The concept analysis on responsible production provides a guidepost to facilitate future studies in this area. We also identify research trends and the main research domains through keyword co-occurrence, co-citation, country collaboration, term co-occurrence, and theme evolution analyses and propose a research framework for future directions. This study contributes knowledge on responsible production research in two aspects. First, we analyze research status, summarize research domains, and identify research development in this emerging field. The findings can provide a general picture of studies on responsible production for scholars to position their studies. Second, we clarify some research gaps implied in the literature and offer guideposts with future research questions for responsible production, especially its link to financial performance. This study is the first attempt to define responsible production and map its research development, as this practice has been highly valued in SDG 12 and business operations. Practically, enterprises are advised to implement responsible production practices to meet the market expectations for corporate reputation. As benchmarking on responsible production is lacking, policymakers can help develop standards for adopters to evaluate their implementation progress and diffuse the practices with benchmark performance measures.

Author Contributions: Conceptualization, F.L.; K.-h.L. and W.C.; Data curation, F.L.; Formal analysis, F.L.; Investigation, F.L. and W.C.; Supervision, K.-h.L.; Writing-original draft, F.L.; Writing—review and editing, F.L.; K.-h.L. and W.C.; Project administration, K.-h.L.; Funding acquisition, K.-h.L. and W.C. All authors have read and agreed to the published version of the manuscript.

Funding: This research was funded by the General Research Fund of Hong Kong Research Grant Council (15500020) and the Hong Kong Scholar Program (XJ2019059).

Institutional Review Board Statement: Not Applicable.

Informed Consent Statement: Not Applicable.

Data Availability Statement: The data presented in this study are available on request from the corresponding author. The data are not publicly available due to the continuation of research and other manuscripts that are in process.

Acknowledgments: We would like to thank all anonymous reviewers for helping give us some suggestions to improve the quality of this manuscript.

Conflicts of Interest: The authors declare no conflict of interest.

\section{References}

1. Cervelló-Royo, R.; Moya-Clemente, I.; Perelló-Marín, M.; Ribes-Giner, G. Sustainable development, economic and financial factors, that influence the opportunity-driven entrepreneurship. An fsQCA approach. J. Bus. Res. 2020, 115, 393-402. [CrossRef]

2. Gunawan, J.; Permatasari, P.; Tilt, C. Sustainable development goal disclosures: Do they support responsible consumption and production? J. Clean. Prod. 2020, 246, 118989. [CrossRef] 
3. OECD. Extended Producer Responsibility: A Guidance Manual for Governments; OECD: Paris, France, 2001.

4. Yan, W.; Chai, J.; Qian, Z.; Tsai, S.B.; Chen, H.; Xiong, Y. Operational decisions on remanufacturing outsourcing involved with corporate environmental and social responsibility-A sustainable perspective. Sustainability 2018, 10, 1132. [CrossRef]

5. Tozanlı, Ö.; Kongar, E.; Gupta, S.M. Trade-in-to-upgrade as a marketing strategy in disassembly-to-order systems at the edge of blockchain technology. Int. J. Prod. Res. 2020, 58, 7183-7200. [CrossRef]

6. United Nations Sustainable Development Goals. Available online: https://sustainabledevelopment.un.org (accessed on 10 November 2020).

7. Zhao, J.S.; Joas, R.; Abel, J.; Marques, T.; Suikkanen, J. Process safety challenges for SMEs in China. J. Loss Prev. Process. Ind. 2013, 26, 880-886. [CrossRef]

8. Skouloudis, A.; Avlonitis, G.J.; Malesios, C.; Evangelinos, K. Priorities and perceptions of corporate social responsibility Insights from the perspective of Greek business professionals. Manag. Decis. 2015, 53, 375-401. [CrossRef]

9. Roy, V.; Singh, S. Mapping the business focus in sustainable production and consumption literature: Review and research framework. J. Clean. Prod. 2017, 150, 224-236. [CrossRef]

10. Geng, D.; Feng, Y.; Zhu, Q. Sustainable design for users: A literature review and bibliometric analysis. Environ. Sci. Pollut. Res. 2020, 27, 29824-29836. [CrossRef]

11. Krolczyk, G.; Maruda, R.; Krolczyk, J.; Wojciechowski, S.; Mia, M.; Nieslony, P.; Budzik, G. Ecological trends in machining as a key factor in sustainable production-A review. J. Clean. Prod. 2019, 218, 601-615. [CrossRef]

12. Engert, S.; Rauter, R.; Baumgartner, R.J. Exploring the integration of corporate sustainability into strategic management: A literature review. J. Clean. Prod. 2016, 112, 2833-2850. [CrossRef]

13. Zimon, D.; Tyan, J.; Sroufe, R. Drivers of sustainable supply chain management: Practices to alignment with un sustainable development goals. Int. J. Qual. Res. 2020, 14, 219-236. [CrossRef]

14. Walker, L.O.; Avant, K.C. Strategies for Theory Construction in Nursing; Prentice Hall: Upper Saddle River, NJ, USA, 2011.

15. Zimmerman, M.S.; Shaw Jr, G. Health information seeking behaviour: A concept analysis. Health Inf. Libr. J. 2020, 37, 173-191. [CrossRef] [PubMed]

16. Castiglione, S.A. Implementation leadership: A concept analysis. J. Nurs. Manag. 2020, 28, 94-101. [CrossRef] [PubMed]

17. van Kemenade, E. Emergence in TQM, a concept analysis. TQM J. 2019, 32, 143-161. [CrossRef]

18. Baines, T.; Brown, S.; Benedettini, O.; Ball, P. Examining green production and its role within the competitive strategy of manufacturers. J. Ind. Eng. Manag. 2012, 5, 53-87. [CrossRef]

19. Stekelorum, R. The roles of SMEs in implementing CSR in supply chains: A systematic literature review. Int. J. Logist. Res. Appl. 2020, 23, 228-253. [CrossRef]

20. Fang, C.C.; Zhang, J.T. Performance of green supply chain management: A systematic review and meta analysis. J. Clean. Prod. 2018, 183, 1064-1081. [CrossRef]

21. Feng, Y.T.; Zhu, Q.H.; Lai, K.H. Corporate social responsibility for supply chain management: A literature review and bibliometric analysis. J. Clean. Prod. 2017, 158, 296-307. [CrossRef]

22. Responsible Production and Consumption. Available online: https://www.azti.es/en/major-challenges/responsible-productionand-consumption/ (accessed on 10 November 2020).

23. Lewis, M.A. Lean production and sustainable competitive advantage. Int. J. Oper. Prod. Manag. 2000, 20, 959-978. [CrossRef]

24. Gotschol, A.; De Giovanni, P.; Vinzi, V.E. Is environmental management an economically sustainable business? J. Environ. Manag. 2014, 144, 73-82. [CrossRef]

25. Bonvoisin, J.; Stark, R.; Seliger, G. Field of research in sustainable manufacturing. In Sustainable Manufacturing; Springer: Cham, Switzerland, 2017; pp. 3-20.

26. Yaacoub, A.M.; Fresner, J. Half Is Enough: An Introduction to Cleaner Production; LCPC Press: Beirut, Lebanon, 2007.

27. Keskin, D.; Diehl, J.C.; Molenaar, N. Innovation process of new ventures driven by sustainability. J. Clean. Prod. 2013, 45, 50-60. [CrossRef]

28. Cappelen, A.; Ognedal, T. Certification and socially responsible production. Econ. Gov. 2017, 18, 71-84. [CrossRef]

29. Hamalainen, E.; Inkinen, T. Industrial applications of big data in disruptive innovations supporting environmental reporting. J. Ind. Inf. Integr. 2019, 16, 100105. [CrossRef]

30. Yong, Y.S.; Lim, Y.A.; Ilankoon, I. An analysis of electronic waste management strategies and recycling operations in Malaysia: Challenges and future prospects. J. Clean. Prod. 2019, 224, 151-166. [CrossRef]

31. Sarkis, J. Manufacturing strategy and environmental consciousness. Technovation 1995, 15, 79-97. [CrossRef]

32. Zhang, H.; Haapala, K.R. Integrating sustainable manufacturing assessment into decision making for a production work cell. J. Clean. Prod. 2015, 105, 52-63. [CrossRef]

33. Mahmood, F.; Qadeer, F.; Sattar, U.; Ariza-Montes, A.; Saleem, M.; Aman, J. Corporate Social Responsibility and Firms' Financial Performance: A New Insight. Sustainability 2020, 12, 4211. [CrossRef]

34. Shin, H.J.; Ellinger, A.E.; Nolan, H.H.; DeCoster, T.D.; Lane, F. An Assessment of the Association Between Renewable Energy Utilization and Firm Financial Performance. J. Bus. Ethics 2018, 151, 1121-1138. [CrossRef]

35. Raut, R.D.; Luthra, S.; Narkhede, B.E.; Mangla, S.K.; Gardas, B.B.; Priyadarshinee, P. Examining the performance oriented indicators for implementing green management practices in the Indian agro sector. J. Clean. Prod. 2019, 215, 926-943. [CrossRef] 
36. Wang, C.H.; Chen, K.S.; Tan, K.H. Lean Six Sigma applied to process performance and improvement model for the development of electric scooter water-cooling green motor assembly. Prod. Plan. Control 2019, 30, 400-412. [CrossRef]

37. Broadstock, D.C.; Managi, S.; Matousek, R.; Tzeremes, N.G. Does doing "good" always translate into doing "well"? An eco-efficiency perspective. Bus. Strategy Environ. 2019, 28, 1199-1217. [CrossRef]

38. Sohn, J.; Lee, J.; Kim, N. Going Green Inside and Out: Corporate Environmental Responsibility and Financial Performance under Regulatory Stringency. Sustainability 2020, 12, 3850. [CrossRef]

39. Xue, B.; Zhang, Z.; Li, P.L. Corporate environmental performance, environmental management and firm risk. Bus. Strategy Environ. 2020, 29, 1074-1096. [CrossRef]

40. Kolbel, J.F.; Busch, T.; Jancso, L.M. How Media Coverage of Corporate Social Irresponsibility Increases Financial Risk. Strateg. Manag. J. 2017, 38, 2266-2284. [CrossRef]

41. Benlemlih, M.; Shaukat, A.; Qiu, Y.; Trojanowski, G. Environmental and Social Disclosures and Firm Risk. J. Bus. Ethics 2018, 152, 613-626. [CrossRef]

42. Zhao, C.G.; Song, H.; Chen, W.Y. Can social responsibility reduce operational risk: Empirical analysis of Chinese listed companies. Technol. Forecast. Soc. Chang. 2016, 112, 145-154. [CrossRef]

43. Kim, J.; Kim, J. Corporate Sustainability Management and Its Market Benefits. Sustainability 2018, 10, 1455. [CrossRef]

44. Agan, Y.; Acar, M.F.; Borodin, A. Drivers of environmental processes and their impact on performance: A study of Turkish SMEs. J. Clean. Prod. 2013, 51, 23-33. [CrossRef]

45. Yang, M.X.; Li, J.; Yu, I.Y.; Zeng, K.J.; Sun, J.M. Environmentally sustainable or economically sustainable? The effect of Chinese manufacturing firms' corporate sustainable strategy on their green performances. Bus. Strategy Environ. 2019, $28,989-997$. [CrossRef]

46. Xu, F.; Yang, M.; Li, Q.Y.; Yang, X.L. Long-term economic consequences of corporate environmental responsibility: Evidence from heavily polluting listed companies in China. Bus. Strategy Environ. 2020, 29, 2251-2264. [CrossRef]

47. Responsible Production. Available online: https://www.teck.com/responsibility/sustainability-topics/responsible-production/ (accessed on 10 November 2020).

48. Huawei's 2018 Sustainability Report. Available online: https://www.huawei.com/en/news/2019/7/huawei-2018-sustainabilityreport (accessed on 10 November 2020).

49. The Fashion Industry Is the Second Largest Polluter in the World. Available online: https://www.sustainyourstyle.org/oldenvironmental-impacts (accessed on 10 November 2020).

50. The Irresponsible Practices of the Palm Oil Industry. Available online: https://planetearth5.com/tag/palm-oil/ (accessed on 10 November 2020).

51. Ali, M.H.; Zailani, S.; Iranmanesh, M.; Foroughi, B. Impacts of Environmental Factors on Waste, Energy, and Resource Management and Sustainable Performance. Sustainability 2019, 11, 2443. [CrossRef]

52. Qian, C.; Wang, S.H.; Liu, X.H.; Zhang, X.Y. Low-Carbon Initiatives of Logistics Service Providers: The Perspective of Supply Chain Integration. Sustainability 2019, 11, 3233. [CrossRef]

53. Haleem, F.; Farooq, S.; Waehrens, B.V. Supplier corporate social responsibility practices and sourcing geography. J. Clean. Prod. 2017, 153, 92-103. [CrossRef]

54. Hasanudin, A.I.; Yuliansyah, Y.; Said, J.; Susilowati, C.; Muafi, M. Management control system, corporate social responsibility, and firm performance. Entrep. Sustain. Issues 2019, 6, 1354-1368. [CrossRef]

55. Vancheswaran, A.; Gautam, V. An appraisal of CSR in SMEs in a globalised context: An empirical study of a ceramic cluster in Morbi, India. Int. J. Glob. Small Bus. 2009, 3, 441-462. [CrossRef]

56. Kim, M.S.; Thapa, B. Relationship of Ethical Leadership, Corporate Social Responsibility and Organizational Performance. Sustainability 2018, 10, 447. [CrossRef]

57. Suganthi, L. Ecospirituality for organizational sustainability: An empirical study. J. Clean. Prod. 2020, 266, 121849. [CrossRef]

58. Orzes, G.; Moretto, A.M.; Moro, M.; Rossi, M.; Sartor, M.; Caniato, F.; Nassimbeni, G. The impact of the United Nations global compact on firm performance: A longitudinal analysis. Int. J. Prod. Econ. 2020, 227, 107664. [CrossRef]

59. Jajja, M.S.S.; Asif, M.; Montabon, F.; Chatha, K.A. The indirect effect of social responsibility standards on organizational performance in apparel supply chains: A developing country perspective. Transp. Res. Part E-Logist. Transp. Rev. 2020, 139, 101968. [CrossRef]

60. Shahzad, M.; Qu, Y.; Javed, S.A.; Zafar, A.U.; Rehman, S.U. Relation of environment sustainability to CSR and green innovation: A case of Pakistani manufacturing industry. J. Clean. Prod. 2020, 253, 119938. [CrossRef]

61. Ikram, M.; Zhou, P.; Shah, S.A.A.; Liu, G.Q. Do environmental management systems help improve corporate sustainable development? Evidence from manufacturing companies in Pakistan. J. Clean. Prod. 2019, 226, 628-641. [CrossRef]

62. Shou, Y.; Shao, J.; Wang, W.; Lai, K.-H. The impact of corporate social responsibility on trade credit: Evidence from Chinese small and medium-sized manufacturing enterprises. Int. J. Prod. Econ. 2020, 230, 107809. [CrossRef]

63. Lloyd-Smith, P.; An, H. Are corporate social responsibility and advertising complements or substitutes in producing firm reputation? Appl. Econ. 2019, 51, 2275-2288. [CrossRef]

64. Pratihari, S.K.; Uzma, S.H. A survey on bankers' perception of corporate social responsibility in India. Soc. Responsib. J. 2019, 16, 225-253. [CrossRef] 
65. Swoboda, B.; Batton, N. Cross-national roles of perceived reputation dimensions for MNCs. Int. Mark. Rev. 2020, 37, 1051-1081. [CrossRef]

66. Yuen, K.F.; Thai, V.V.; Wong, Y.D.; Wang, X.Q. Interaction impacts of corporate social responsibility and service quality on shipping firms' performance. Transp. Res. Part A-Policy Pract. 2018, 113, 397-409. [CrossRef]

67. Wei, W.; Kim, G.; Miao, L.; Behnke, C.; Almanza, B. Consumer inferences of corporate social responsibility (CSR) claims on packaged foods. J. Bus. Res. 2018, 83, 186-201. [CrossRef]

68. Zhou, H.D.; Wang, Q.; Zhao, X.D. Corporate social responsibility and innovation: A comparative study. Ind. Manag. Data Syst. 2020, 120, 863-882. [CrossRef]

69. Ali, H.Y.; Asrar-ul-Haq, M.; Amin, S.; Noor, S.; Haris-ul-Mahasbi, M.; Aslam, M.K. Corporate social responsibility and employee performance: The mediating role of employee engagement in the manufacturing sector of Pakistan. Corp. Soc. Responsib. Environ. Manag. 2020, 27, 2908-2919. [CrossRef]

70. John, A.; Qadeer, F.; Shahzadi, G.; Jia, F. Getting paid to be good: How and when employees respond to corporate social responsibility? J. Clean. Prod. 2019, 215, 784-795. [CrossRef]

71. Appiah, J.K. Community-based corporate social responsibility activities and employee job satisfaction in the U.S. hotel industry: An explanatory study. J. Hosp. Tour. Manag. 2019, 38, 140-148. [CrossRef]

72. Gubler, T.; Larkin, I.; Pierce, L. Doing Well by Making Well: The Impact of Corporate Wellness Programs on Employee Productivity. Manag. Sci. 2018, 64, 4967-4987. [CrossRef]

73. Song, H.; Yu, K.; Zhang, S. Green procurement, stakeholder satisfaction and operational performance. Int. J. Logist. Manag. 2017, 28, 1054-1077. [CrossRef]

74. Iranmanesh, M.; Fayezi, S.; Hanim, S.; Hyun, S.S. Drivers and outcomes of eco-design initiatives: A cross-country study of Malaysia and Australia. Rev. Manag. Sci. 2019, 13, 1121-1142. [CrossRef]

75. Budgen, D.; Brereton, P. Performing systematic literature reviews in software engineering. In Proceedings of the 28th International Conference on Software Engineering, Shanghai, China, 20-28 May 2006; pp. 1051-1052.

76. Briner, R.B.; Denyer, D.; Rousseau, D.M. Evidence-Based Management: Concept Cleanup Time? Acad. Manag. Perspect. 2009, 23, 19-32. [CrossRef]

77. Abualfaraa, W.; Salonitis, K.; Al-Ashaab, A.; Ala'raj, M. Lean-Green Manufacturing Practices and Their Link with Sustainability: A Critical Review. Sustainability 2020, 12, 981. [CrossRef]

78. Zupic, I.; Cater, T. Bibliometric Methods in Management and Organization. Organ. Res. Methods 2015, 18, 429-472. [CrossRef]

79. van Eck, N.J.; Waltman, L. Software survey: VOSviewer, a computer program for bibliometric mapping. Scientometrics 2010, 84, 523-538. [CrossRef]

80. Chen, C.M. CiteSpace II: Detecting and visualizing emerging trends and transient patterns in scientific literature. J. Am. Soc. Inf. Sci. Technol. 2006, 57, 359-377. [CrossRef]

81. Elkington, J. Cannibals with Forks: The Triple Bottom Line of Twenty-First Century Business; Capstone Publishing: Oxford, UK, 1997.

82. Rockström, J. Bounding the planetary future: Why we need a great transition. Great Transit. Initiat. 2015, 9, 1-13.

83. Cherrafi, A.; Elfezazi, S.; Govindan, K.; Garza-Reyes, J.A.; Benhida, K.; Mokhlis, A. A framework for the integration of Green and Lean Six Sigma for superior sustainability performance. Int. J. Prod. Res. 2017, 55, 4481-4515. [CrossRef]

84. Abdul-Rashid, S.H.; Sakundarini, N.; Ghazilla, R.A.R.; Thurasamy, R. The impact of sustainable manufacturing practices on sustainability performance Empirical evidence from Malaysia. Int. J. Oper. Prod. Manag. 2017, 37, 182-204. [CrossRef]

85. Zarte, M.; Pechmann, A.; Nunes, I.L. Decision support systems for sustainable manufacturing surrounding the product and production life cycle-A literature review. J. Clean. Prod. 2019, 219, 336-349. [CrossRef]

86. Geng, R.Q.; Mansouri, A.; Aktas, E. The relationship between green supply chain management and performance: A meta-analysis of empirical evidences in Asian emerging economies. Int. J. Prod. Econ. 2017, 183, 245-258. [CrossRef]

87. Soheilirad, S.; Govindan, K.; Mardani, A.; Zavadskas, E.K.; Nilashi, M.; Zakuan, N. Application of data envelopment analysis models in supply chain management: A systematic review and meta-analysis. Ann. Oper. Res. 2018, 271, 915-969. [CrossRef]

88. Zhu, W.W.; Wang, Z.Q. The Collaborative Networks and Thematic Trends of Research on Purchasing and Supply Management for Environmental Sustainability: A Bibliometric Review. Sustainability 2018, 10, 1510. [CrossRef]

89. van Marrewijk, M.; Werre, M.; Hardjono, T.W.; Panapanaan, V.M.; Linnanen, L.; Keeble, J.J.; Topiol, S.; Berkeley, S.; Roberts, S.; Timmers, J.; et al. Corporate Sustainability Conference 2002: The impact of CSR on management disciplines. J. Bus. Ethics 2003, 44, 89-93.

90. Lukman, R.K.; Glavič, P.; Carpenter, A.; Virtič, P. Sustainable consumption and production-Research, experience, and development-The Europe we want. J. Clean. Prod. 2016, 138, 139-147. [CrossRef]

91. Niesten, E.; Lozano, R. Making, buying and collaborating for more sustainable production and consumption. J. Clean. Prod. 2015, 100, 1-3. [CrossRef]

92. He, C.; Wu, J.; Zhang, Q. Research Leadership Flow Determinants and the Role of Proximity in Research Collaborations. J. Assoc. Inf. Sci. Technol. 2019, 71, 1341-1356. [CrossRef]

93. Zitt, M.; Lelu, A.; Bassecoulard, E. Hybrid Citation-Word Representations in Science Mapping: Portolan Charts of Research Fields? J. Am. Soc. Inf. Sci. Technol. 2011, 62, 19-39. [CrossRef]

94. Huang, Y.; Schuehle, J.; Porter, A.L.; Youtie, J. A systematic method to create search strategies for emerging technologies based on the Web of Science: Illustrated for 'Big Data'. Scientometrics 2015, 105, 2005-2022. [CrossRef] 
95. Orlitzky, M.; Schmidt, F.L.; Rynes, S.L. Corporate social and financial performance: A meta-analysis. Organ. Stud. 2003, 24, 403-441. [CrossRef]

96. Hull, C.E.; Rothenberg, S. Firm performance: The interactions of corporate social performance with innovation and industry differentiation. Strateg. Manag. J. 2008, 29, 781-789. [CrossRef]

97. Luo, X.M.; Bhattacharya, C.B. Corporate social responsibility, customer satisfaction, and market value. J. Mark. 2006, 70, 1-18. [CrossRef]

98. Carroll, A.B. A three-dimensional conceptual model of corporate performance. Acad. Manag. Rev. 1979, 4, 497-505. [CrossRef]

99. Carroll, A.B. The pyramid of corporate social responsibility: Toward the moral management of organizational stakeholders. Bus. Horiz. 1991, 34, 39-48. [CrossRef]

100. McWilliams, A.; Siegel, D. Corporate social responsibility and financial performance: Correlation or misspecification? Strateg. Manag. J. 2000, 21, 603-609. [CrossRef]

101. Margolis, J.D.; Walsh, J.P. Misery loves companies: Rethinking social initiatives by business. Adm. Sci. Q. 2003, 48, 268-305. [CrossRef]

102. Fornell, C.; Larcker, D.F. Evaluating structural equation models with unobservable variables and measurement error. J. Mark. Res. 1981, 18, 39-50. [CrossRef]

103. Waddock, S.A.; Graves, S.B. The corporate social performance-Financial performance link. Strateg. Manag. J. 1997, 18, 303-319. [CrossRef]

104. Russo, M.V.; Fouts, P.A. A resource-based perspective on corporate environmental performance and profitability. Acad. Manag. J. 1997, 40, 534-559. [CrossRef]

105. Hart, S.L. A natural-resource-based view of the firm. Acad. Manag. Rev. 1995, 20, 986-1014. [CrossRef]

106. McWilliams, A.; Siegel, D. Corporate social responsibility: A theory of the firm perspective. Acad. Manag. Rev. 2001, 26, 117-127. [CrossRef]

107. Sen, S.; Bhattacharya, C.B. Does doing good always lead to doing better? Consumer reactions to corporate social responsibility. J. Mark. Res. 2001, 38, 225-243. [CrossRef]

108. McGuire, J.B.; Sundgren, A.; Schneeweis, T. Corporate social-responsibility and firm financial performance. Acad. Manag. J. 1988, $31,854-872$.

109. Turban, D.B.; Greening, D.W. Corporate social performance and organizational attractiveness to prospective employees. Acad. Manag. J. 1997, 40, 658-672. [CrossRef]

110. Carroll, A.B.; Shabana, K.M. The Business Case for Corporate Social Responsibility: A Review of Concepts, Research and Practice. Int. J. Manag. Rev. 2010, 12, 85-105. [CrossRef]

111. Aupperle, K.E.; Carroll, A.B.; Hatfield, J.D. An empirical-examination of the relationship between corporate social-responsibility and profitability. Acad. Manag. J. 1985, 28, 446-463.

112. Klassen, R.D.; McLaughlin, C.P. The impact of environmental management on firm performance. Manag. Sci. 1996, 42, 1199-1214. [CrossRef]

113. Dahlsrud, A. How Corporate Social Responsibility is Defined: An Analysis of 37 Definitions. Corp. Soc. Responsib. Environ. Manag. 2008, 15, 1-13. [CrossRef]

114. Campbell, J.L. Why would corporations behave in socially responsible ways? An institutional theory of corporate social responsibility. Acad. Manag. Rev. 2007, 32, 946-967. [CrossRef]

115. Ellegaard, O.; Wallin, J.A. The bibliometric analysis of scholarly production: How great is the impact? Scientometrics 2015, 105, 1809-1831. [CrossRef] [PubMed]

116. Wood, D.J. Measuring Corporate Social Performance: A Review. Int. J. Manag. Rev. 2010, 12, 50-84. [CrossRef]

117. Godfrey, P.C.; Merrill, C.B.; Hansen, J.M. The relationship between corporate social responsibility and shareholder value: An empirical test of the risk management hypothesis. Strateg. Manag. J. 2009, 30, 425-445. [CrossRef]

118. McWilliams, A.; Siegel, D.S.; Wright, P.M. Corporate social responsibility: Strategic implications. J. Manag. Stud. 2006, 43, 1-18. [CrossRef]

119. Chang, Y.W.; Huang, M.H.; Lin, C.W. Evolution of research subjects in library and information science based on keyword, bibliographical coupling, and co-citation analyses. Scientometrics 2015, 105, 2071-2087. [CrossRef]

120. Ageron, B.; Gunasekaran, A.; Spalanzani, A. Sustainable supply management: An empirical study. Int. J. Prod. Econ. 2012, 140, 168-182. [CrossRef]

121. Rajesh, R.; Rajendran, C. Relating Environmental, Social, and Governance scores and sustainability performances of firms: An empirical analysis. Bus. Strategy Environ. 2020, 29, 1247-1267. [CrossRef]

122. Shi, Y.; Liu, X. Research on the literature of green building based on the Web of Science: A scientometric analysis in CiteSpace (2002-2018). Sustainability 2019, 11, 3716. [CrossRef]

123. Gao, J.; Woodward, A.; Vardoulakis, S.; Kovats, S.; Wilkinson, P.; Li, L.; Xu, L.; Li, J.; Yang, J.; Cao, L. Haze, public health and mitigation measures in China: A review of the current evidence for further policy response. Sci. Total Environ. 2017, 578, 148-157. [CrossRef] [PubMed] 
124. Zhu, Q.; Zhang, Q. Evaluating practices and drivers of corporate social responsibility: The Chinese context. J. Clean. Prod. 2015, 100, 315-324. [CrossRef]

125. Seibert, S.E.; Kacmar, K.M.; Kraimer, M.L.; Downes, P.E.; Noble, D. The role of research strategies and professional networks in management scholars' productivity. J. Manag. 2017, 43, 1103-1130. [CrossRef] 